Article

\title{
First-Order Estimation of In-Place Gas Resources at the Nyegga Gas Hydrate Prospect, Norwegian Sea
}

\author{
Kim Senger $^{1,2, \star}$, Stefan Bünz ${ }^{1}$ and Jürgen Mienert ${ }^{1}$ \\ ${ }^{1}$ Department of Geology, University of Troms $\varnothing$, Dramsveien 201, N-9037 Troms $\varnothing$, Norway; \\ E-Mails: stefan.buenz@uit.no (S.B.); jurgen.mienert@uit.no (J.M.) \\ ${ }^{2}$ Center for Integrated Petroleum Research, Uni Research, Allégaten 41, N-5020 Bergen, Norway \\ * Author to whom correspondence should be addressed; E-Mail: kim.senger@uni.no; \\ Tel.: +47-95291592; Fax: +47-55588265.
}

Received: 26 October 2010; in revised form: 7 December 2010 / Accepted: 20 December 2010 / Published: 22 December 2010

\begin{abstract}
Gas hydrates have lately received increased attention as a potential future energy source, which is not surprising given their global and widespread occurrence. This article presents an integrated study of the Nyegga site offshore mid-Norway, where a gas hydrate prospect is defined on the basis of a multitude of geophysical models and one shallow geotechnical borehole. This prospect appears to hold around $625 \mathrm{GSm}^{3}\left(\mathrm{GSm}^{3}=10^{9}\right.$ standard cubic metres) of gas. The uncertainty related to the input parameters is dealt with through a stochastic calculation, giving a spread of in-place volumes of $183 \mathrm{GSm}^{3}$ (P90) to $1431 \mathrm{GSm}^{3}$ (P10). The resource density for Nyegga is found to be comparable to published resource assessments of other global hydrate provinces.
\end{abstract}

Keywords: methane hydrate; energy resource; mid-Norwegian margin; prospect evaluation; unconventional gas resource

\section{Introduction: Gas Hydrate as an Energy Resource}

Gas hydrates are solid compounds of guest gas molecules set in a rigid cage of host water molecules, occurring at specific pressure-temperature (P-T) conditions beneath the world's oceans and below the permafrost [1,2]. 
Originally a mere scientific curiosity, gas hydrates have attracted much attention since being reported in hydrocarbon pipelines as early as 1934 [3]. Flow assurance remains a problem in the global oil and gas industry to the present day [4,5], with deep-water production and ever longer tie-back distances calling for sophisticated hydrate flow management. Furthermore, gas hydrate dissociation in sediments along continental margins has been linked to potential for large-scale slope failures [6], reduced integrity of man-made seafloor structures due to hydrate-associated slope instability [7] and atmospheric release of methane linking into the wider issue of climate change [8-10].

However, in the past decade gas hydrates are also increasingly considered as a potential energy source. The global energy market is in disharmony, with falling oil production unable to supply the increasing global demand in the long term [11], financial crisis notwithstanding. Production of natural gas is already replacing oil as the dominant hydrocarbon produced in regions close to infrastructure and markets, as on the Norwegian Continental Shelf (NCS). Natural gas, with its lower per unit energy $\mathrm{CO}_{2}$ emissions than any other fossil fuel, is set to provide a large part of the supply necessary to satisfy a predicted 50-60\% global energy demand increase in the period 2008-2030 [12]. Unconventional gas resources, such as tight sands, shale gas or coal bed methane, may ease some of the load off conventional gas resources, provided that their production remains environmentally, technically and commercially acceptable. In addition, gas hydrates can also be considered as an unconventional gas resource [13].

The production of gas hydrates has, to date, utilized slightly modified conventional oil \& gas production technologies. For the guest gas to be produced, the solid ice cage must be broken down by displacing the hydrate out of its P-T stability zone. This is achieved by depressurisation, thermal stimulation or chemical inhibition, or a combination thereof. Both numerical studies, including the use of hydrate-specific reservoir simulators [14-16], and field experience from the Siberian gas field Messoyakha [5,17,18], the North Slope Borough [19] and the Mallik test site [20,21], point to depressurization being the most cost-effective and efficient method. In this scenario, the free gas zone trapped beneath the impermeable hydrate layer is produced, lowering the pressure, and thus allowing the overlying hydrate to dissociate and contribute to the gas flow. However, every prospect is different and the applied production strategy will, as for conventional gas deposits, depend on the geological setting and the hydrate reservoir properties [22].

Gas hydrates are a global and abundant resource. Recent conservative estimates of global hydrate-bound methane, while significantly reduced from the enormous estimates published in the 1980s and 1990s [23], suggest hydrate-derived methane to be an important carbon reservoir [1,2]. While most of these resources occur in low-saturation marine sediments, as illustrated by the resource pyramid of Boswell et al. [24], the potential societal gain of hydrates cannot be ignored. A recent review of the Alaskan gas hydrate resources, as an example, indicates up to $2400 \mathrm{GSm}^{3}$ $\left(\mathrm{GSm}^{3}=10^{9}\right.$ standard cubic metres; 85 trillion cubic feet; equivalent to 15095 million barrels of oil equivalents) of technically recoverable gas [25]. Furthermore, production of gas from some hydrate deposits is possible with only minor modifications of conventional technologies [26]. Most importantly, it has already been tested during short-term scientific production tests at Mallik, a multinational study site in the Canadian Mackenzie Delta [20,21,27,28]. Extensive marine expeditions undertaken as part of ambitious national "hydrate as a resource" programs offshore India [29], Japan [30] and Korea [31], as well as a Joint Industry Project in the Gulf of Mexico [32,33] and numerous ODP/IODP cruises [34,35], 
provide a substantial database for examining various global hydrate provinces in terms of reservoir characterization and prospect definition.

Here we present such a study for the Nyegga prospect, a gas hydrate prospect located in predominantly unlicensed acreage on the northern flank of the Storegga slide, offshore mid-Norway.

\section{Geologic Setting: The Nyegga Gas Hydrate System}

Our study area, referred to as Nyegga in literature, lies on the Vøring Plateau some $135 \mathrm{~km}$ north of Ormen Lange, Norway's second largest gas field (Figure 1). The nearest conventional field, Kristin, is located approximately $80 \mathrm{~km}$ to the north-east. Lying alongside the prolific gas province of the Norwegian Sea is important for several reasons. Firstly, deep thermogenic gas may contribute as a local source to some of the hydrate deposits, as observed in parts of the Gulf of Mexico [36]. Secondly, the existing infrastructure suits itself to cost-effective tie-back solutions should hydrate deposits be developed in the future. Last but not least, the amount of data available for the study of hydrates, in part thanks to the thorough work that went into the Ormen Lange development [37], makes a good foundation for a quantification study.

The Nyegga area has been shaped by a combination of lasting tectonically-driven processes and more recent glacial activity. Multiple rifting episodes resulted in the opening of the Norwegian-Greenland Sea around 55 million years ago, leading to the development of the Møre and Vøring sedimentary basins [39,40]. The Late Eocene strike-slip compressive regime resulted in the development of north-south trending anticlinal features [41], of which the Ormen Lange dome is one. Within the last 3 million years, extensive deposition of glacially derived materials of the Naust Formation dominated the area, resulting in a sediment package well over $1000 \mathrm{~m}$ thick in places [42]. Its depositional regime is highly dependent on the climatic variations associated with glacial and interglacial times and the position of the ice sheet in relation to the shelf break [43].

The study area lies within the Norwegian-Greenland Sea, in which oceanic circulation is governed by the northward-flowing waters of the North Atlantic Current (NAC). Studies of benthic microfossil assemblages during ODP Leg 104 have confirmed that the modern-day oceanic conveyor system was established already during the mid-Miocene [44]. The NAC, essentially the continuation of the North Atlantic Drift, transports warm saline waters into the Nordic Seas. Upon entering the Norwegian-Greenland Sea through the Faroe-Shetland inflow, the NAC is partially branched as the south-easterly flowing Norwegian Channel Inflow. In addition, the Norwegian Coastal Current (3-18 ${ }^{\circ} \mathrm{C}$, Klitgaard-Kristensen et al. [45]) flows along the Norwegian coast, being strongly controlled by seasonal variation. A large publicly available data set [46] allows the examination of 1070 Conductivity-Temperature-Depth (CTD) casts within the study area. The data clearly show the largest variation within the uppermost $200 \mathrm{~m}$ of the water column. At depths exceeding approximately $750 \mathrm{~m}$, temperatures are stable at approximately $-1{ }^{\circ} \mathrm{C}$. Between $\sim 250 \mathrm{~m}$ and $\sim 750 \mathrm{~m}$ there is a large variation in oceanic temperatures of up to $8^{\circ} \mathrm{C}$. 
Figure 1. Location of the Nyegga study area, offshore mid-Norway. The study area rests on the north flank of the Storegga slide, approximately $135 \mathrm{~km}$ north of the Ormen Lange gas field. The main Nyegga gas hydrate prospect, based on the interpretation of the bottom simulating reflection (BSR), is emphasized in yellow. A detailed map illustrating the extent of the gas hydrate zone, as well as the key data used is provided in Figure 4. Figure modified from Weibull et al. [38].

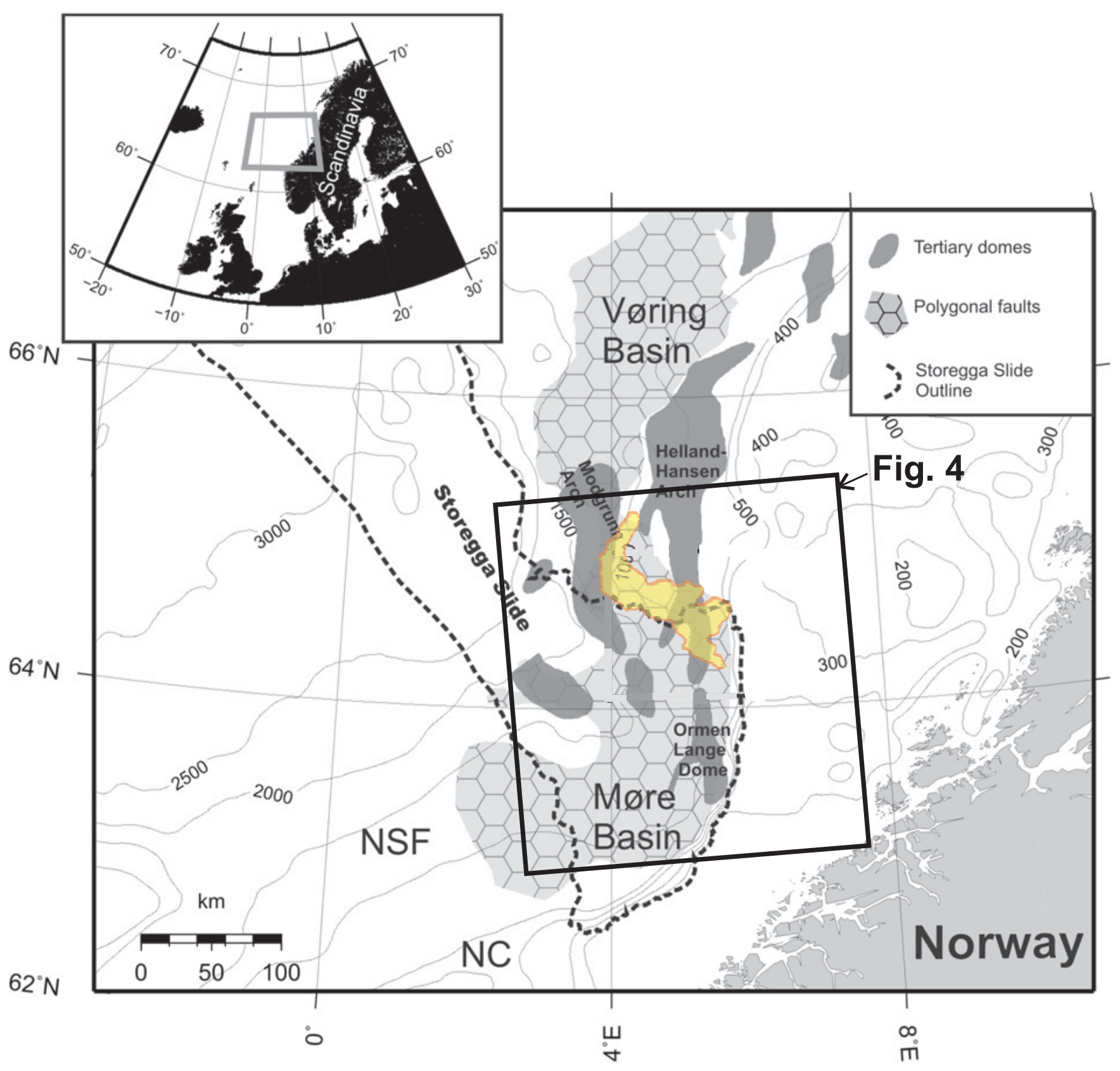


Gas hydrates have originally been inferred from the Nyegga area on the basis of bottom-simulating reflections (BSRs) [47-49] as well as seabed topography and biology [50,51]. Physical sampling of shallow gas hydrates was first reported in 2006 [52], though the Nyegga gas hydrates have long been studied "geophysically" [53-55]. It is notable that a shallow geotechnical borehole, 6404/5 GB1, penetrated the BSR during a drilling campaign in 1997. While the vertical seismic profiling (VSP) suggest the presence of hydrates, no physical samples were recovered at this time, probably due to a lack in suitable pressure-coring equipment. While gas hydrate saturations have been estimated in places through the use of various inversions of ocean bottom seismic (OBS) and high-resolution 3D seismic data [56-58], no one has, to the best of our knowledge, previously attempted to calculate the total amount of methane encaged within the Nyegga gas hydrate province.

Quantifying gas hydrate deposits, at Nyegga or otherwise, is important for three main reasons:

1. Modeling potential release of the potent greenhouse gas methane into the ocean following a shift in P-T conditions;

2. Risk assessment for conventional exploration boreholes targeting hydrocarbons beneath zones of notoriously unstable gas hydrate;

3. Providing an estimate of the scale and potential of the hydrate deposit as a future energy resource.

This study focuses on Point 3, yet the methods and results presented could easily be modified to suit other objectives. It must be noted that this study's objective was to define a range of probable in-place (GIIP) volumes, and further work remains on evaluating whether the hydrate deposits can technically be recovered.

\section{Methods}

\subsection{Modeling the Hydrate Stability Zone}

In order to constrain the Nyegga gas hydrate system in two dimensions, a thermobaric model was established to calculate the extent of the hydrate stability zone (HSZ, Figure 2, [59]). The HSZ is defined on the basis of the hydrate phase boundary, the geothermal gradient and the oceanic thermal gradient. A matrix of cases was established to examine the relative impact of altering the various input parameters. Finally, the modeled base of the HSZ was compared with the BSR observed on seismic data (Figure 3). A good fit confirms that the BSR is likely to be a hydrate-related reflection.

\subsection{Prospect Evaluation}

Our methodology closely follows that of traditional prospect evaluation of conventional hydrocarbon prospects. To begin with, an integrated database of seismic, borehole and oceanographic data was established (Figure 4). The Nyegga prospect is modeled as a 3-segment unit (Figure 5), consisting of a solid gas hydrate zone, a gaseous free gas zone and a combination chimney zone. 
Figure 2. Input parameters used to define the thermobaric hydrate stability zone (HSZ) model. (a) Hydrate phase boundary; (b) Geothermal gradients; (c) Oceanic thermal gradients; (d) The complete system plotted on the pressure-temperature diagram. The model is kept on the same scale to allow for comparison of the effect of the various parameters. Pressure is given in decibars $(\mathrm{db})$.

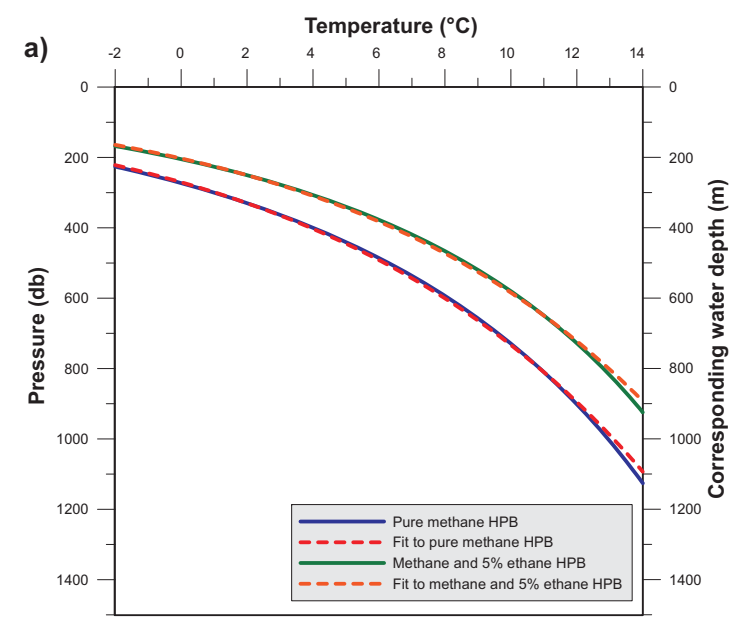

c)

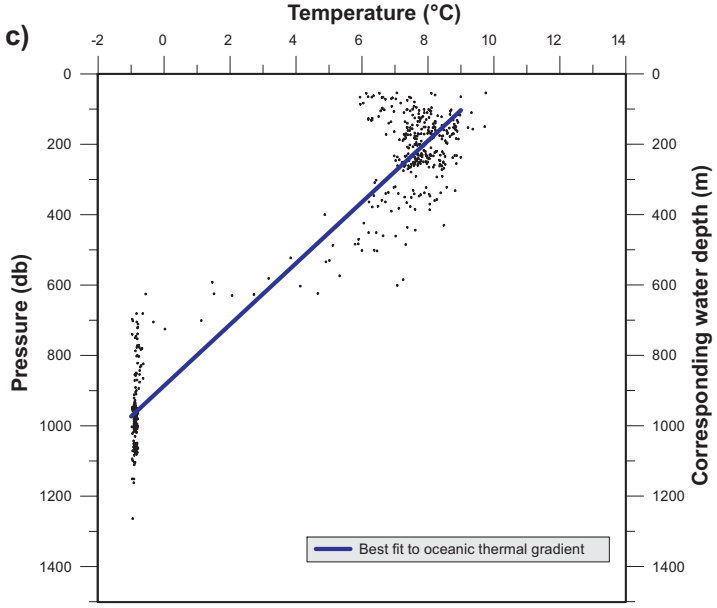

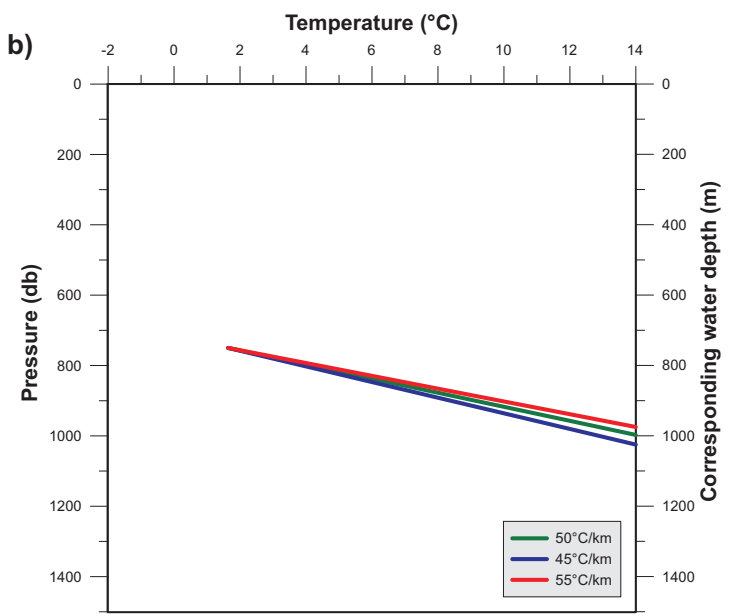

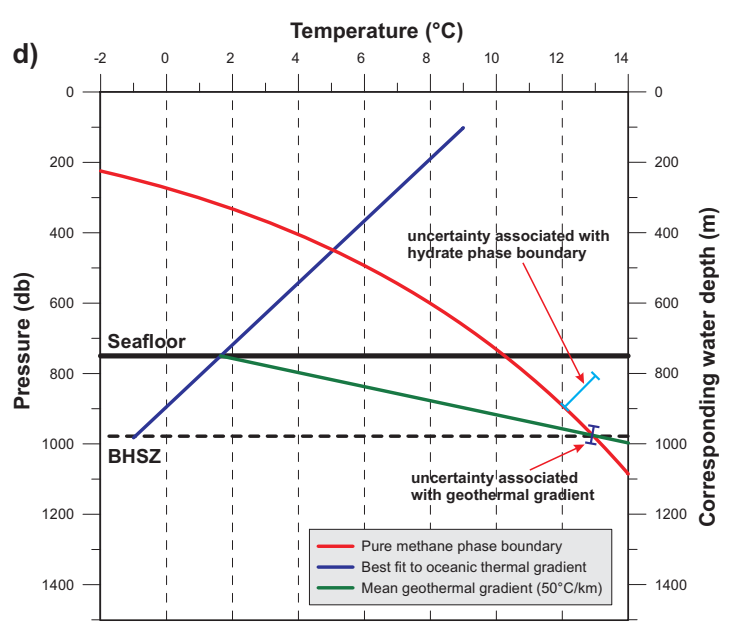

Figure 3. Modeled HSZ extent (red areas = hydrate can form) compared to the bottom-simulating reflection (stippled yellow line) as observed on 2D line JMF97-215. This particular model is based on a pure methane system with saline pore water, a high geothermal gradient and an average oceanic thermal gradient.

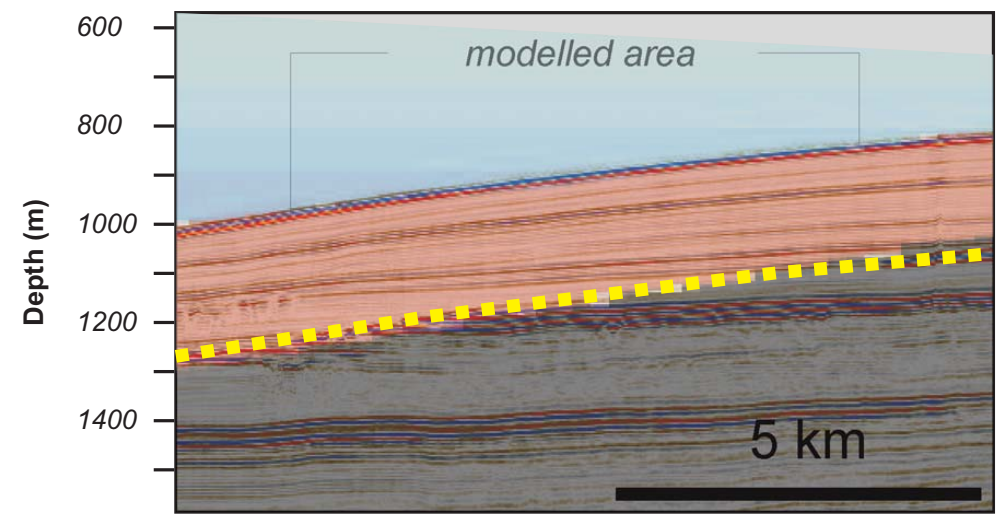


Figure 4. Location map showing the data, including seismic, borehole and oceanographic data, used to generate the 3D model. Please note that the stippled yellow lines indicate 2D seismic data used to tie the key 2D seismic data set, JMF97 (pink solid lines), to the wells. Also note that the study area only contains the largest BSR extent, while other prospects where BSRs are identified provide an upside potential.

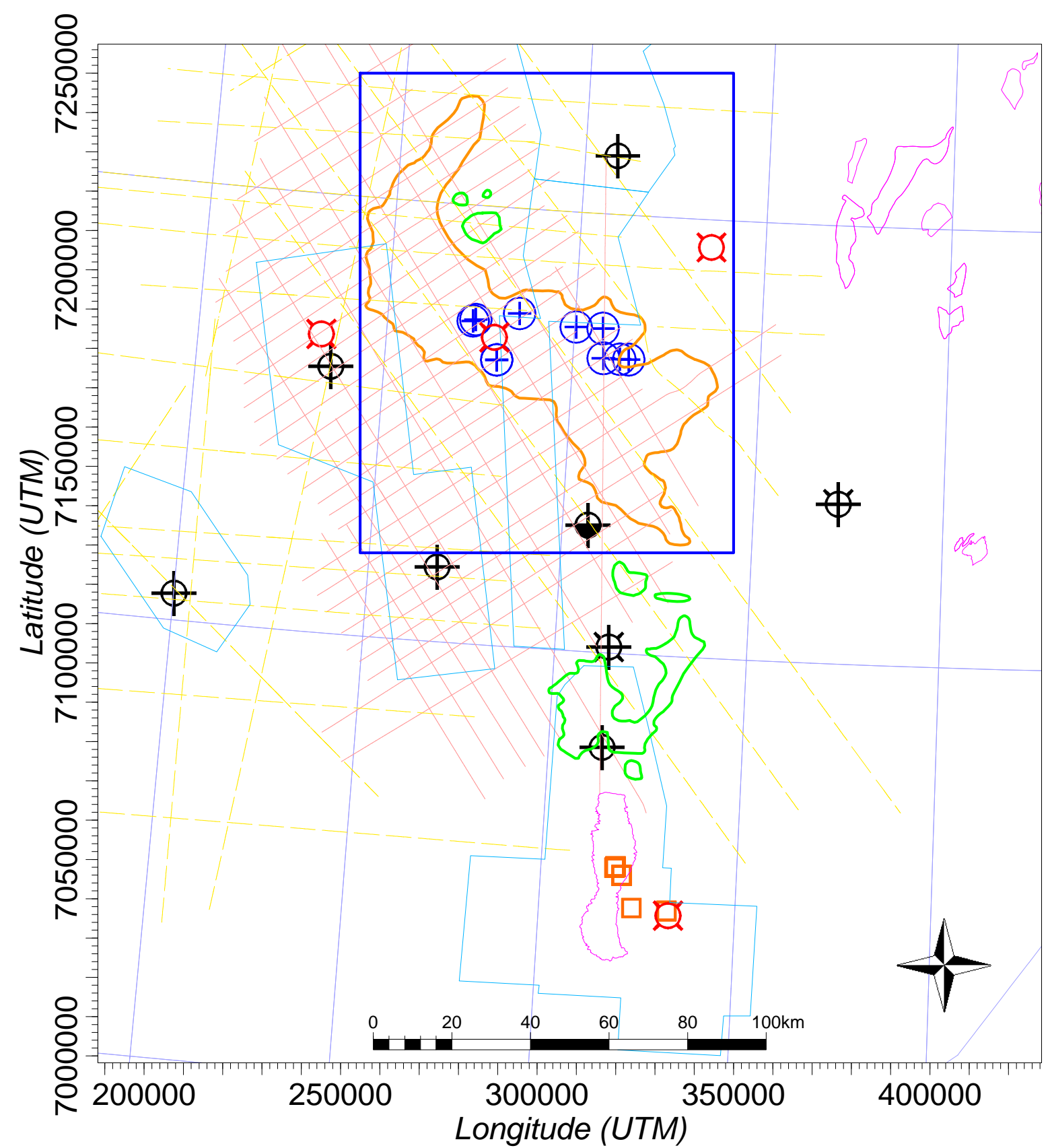

Nyegga 3D model outline
Nyegga prospect outline
Quadrant boundaries
Conventional oil \& gas fields
3D seismic coverage
Other areas with BSRs
\% Dry, plugged and abandoned

Minor oil, plugged and abandoned Minor gas, plugged and abandoned CTD stations

a. Shallow geotechnical boreholes

$\oplus$ OBS stations

Gas, plugged and abandoned 
Figure 5. A cartoon sketch of the Nyegga prospect definition based on seismic line NH9651-202, showing its three main segments; (1) The gas hydrate zone, 10-120 m thick; (2) The free gas zone, 20-80 m thick; (3) The chimney zone, on average $200 \mathrm{~m}$ wide. The bottom-simulating reflection (BSR) is highlighted with arrows. The BSR is most marked within permeable intervals where the free gas to gas hydrate transition causes a strong and sharp amplitude change. The geotechnical borehole, 6404/5 GB1, has been used to constrain porosity. The polygonal fault system within the underlying Kai Formation provides pathways for fluid and gaseous flow [54]. Figure modified from Bünz and Mienert [57].

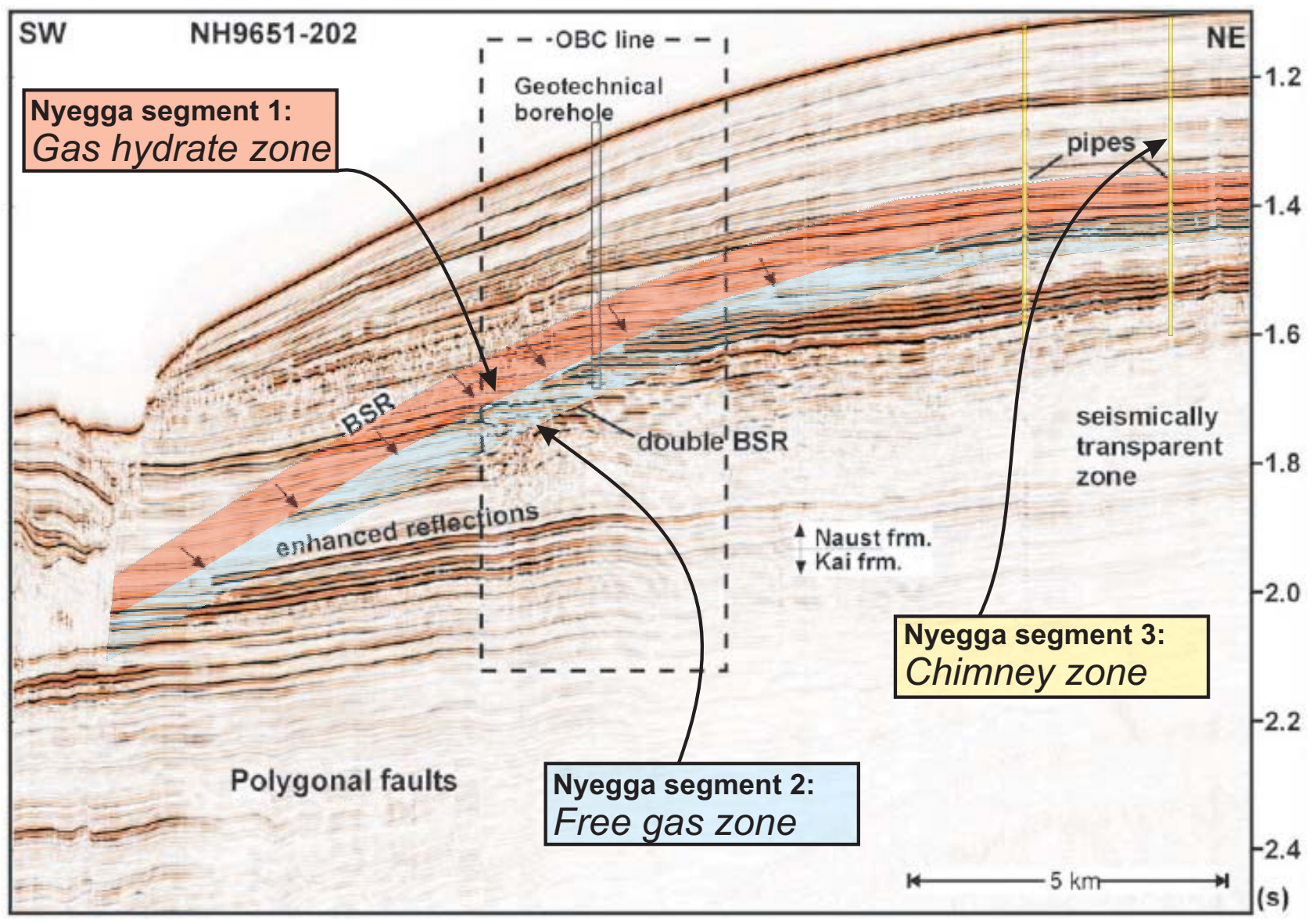

While both the gas hydrate and the free gas zones are spatially defined by the BSR, the chimney zone is based on an integrated study of Weibull [60]. Weibull used both multibeam echosounder data and the GH2001 high-resolution seismic survey to generate a well-documented geostatistical overview of gas-related features across part of the Nyegga prospect. While the physical content of acoustic chimneys is an ongoing debate [61], potential for higher saturation hydrate accumulations exists in such pipes due to focused fluid flux and they have thus been included as a separate segment in our volumetric calculation.

A standard volumetric calculation (Equation 1, Figure 6) was implemented in two industry-standard tools, Petrel and GeoX. To account for the uncertainty with respect to data sampling across the Nyegga prospect, a wide range of probable reservoir parameters was used as input (Table 1). 
Figure 6. A sketch illustrating the Nyegga volumetric calculation. The three-dimensional reservoir extent is calculated based on the areal extent of the bottom-simulating reflection (BSR) and the thickness of the hydrate and free gas zones, based on ocean bottom seismometer (OBS) experiments. For the chimney zone, the gross rock volume (GRV) is directly defined by the study of Weibull [60]. Net-to-gross (NTG), porosity and gas hydrate saturation is applied to give a hydrocarbon pore volume (HCPV). Upon application of an expansion factor, $B_{G}$, a gas initially in place (GIIP) volume is calculated. Only a fraction of the GIIP is technically producible, depending on the recovery factor, to give the final recoverable gas. Please note that GIIP equates in-place volumes.

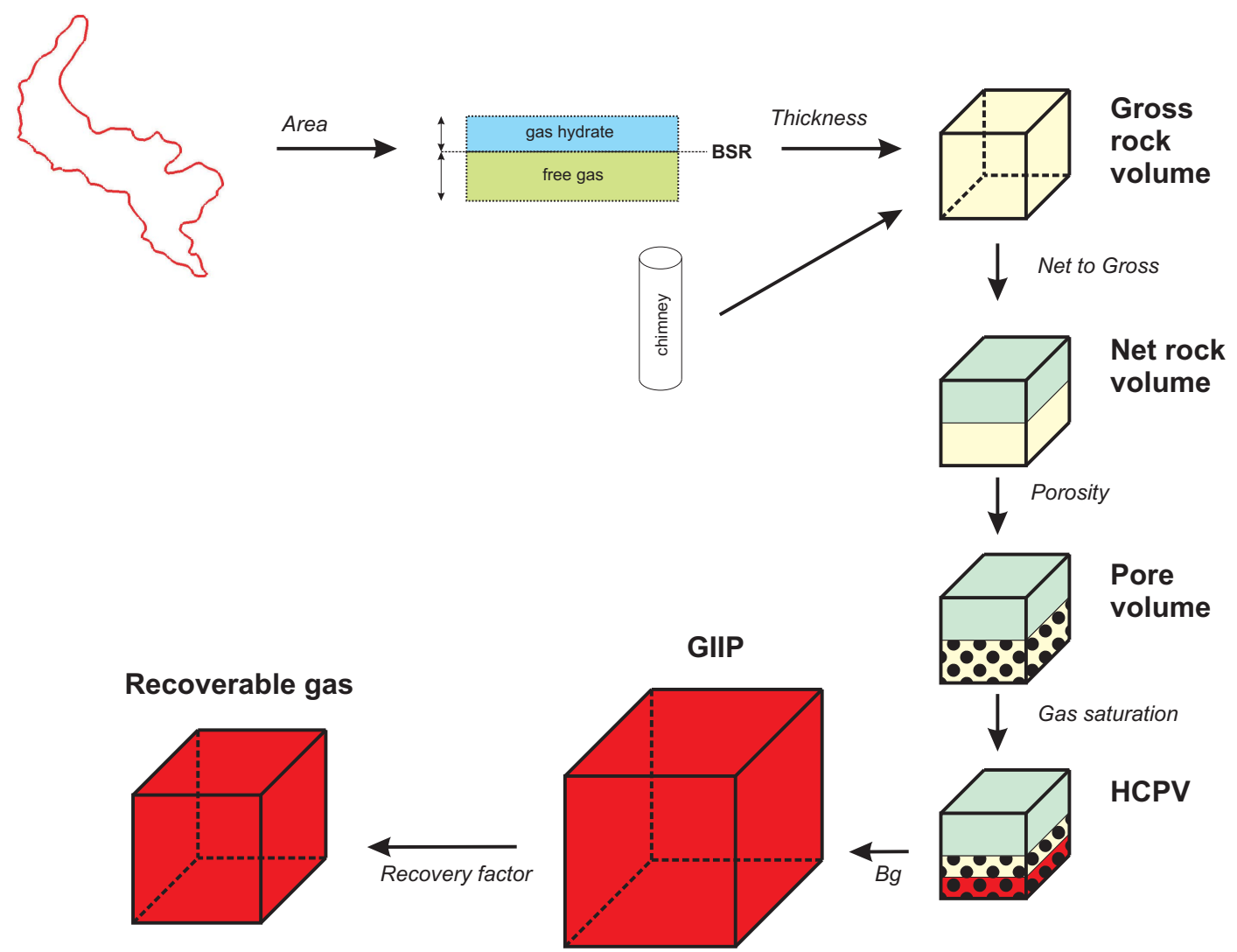

The total in-place gas, $Q_{\text {gas }}$, is defined by:

$$
[! h] Q_{\text {gas }}=B R V \times \phi \times N / G \times\left(1-S_{W}\right) \times \frac{1}{B_{G}}
$$

where:

$B R V=$ Bulk rock volume, $\mathrm{m}^{3}$;

$\phi=$ porosity, given as fraction of 1 ;

$N / G=$ Net to gross ratio of sand, given as fraction of 1 ;

$S_{W}=$ Water saturation, given as fraction of 1 ;

$B_{G}=$ Compressibility of gas, defined by volume at reservoir/volume at STP. 


\subsection{Reservoir Parameters}

Input parameters were defined by distributions, spanning in both directions from a base case representing the most likely case (Table 1 and Figure 7).

Table 1. Range of reservoir parameters used in defining the in-place volumes of hydrate-bound methane. Each reservoir parameter is defined by a distribution between a range of possible values used in the stochastic calculation. The mode case will, by definition, have the highest impact in the volumetric calculation and thus represents the most favoured case. Note that StrBeta $=$ Stretched Beta distribution.

\begin{tabular}{|c|c|c|c|c|c|}
\hline \multirow[b]{2}{*}{ Parameter [units] } & \multicolumn{4}{|c|}{ Gas hydrate zone } & \multirow[t]{2}{*}{ Reference/Comments } \\
\hline & Type & Min & Base & Max & \\
\hline Area of Closure [km2] & StrBeta & 1070 & 2254 & 3120 & $\begin{array}{l}\text { Mid case: BSR outline without "tricky" zones, Low case: "Sweet } \\
\text { spot" BSR outline, High case: BSR outline. }\end{array}$ \\
\hline Net/Gross Ratio [decimal] & Normal & 0.001 & 0.5 & 1 & Based on Hustoft et al 2007 \& Bouriak et al 2003. \\
\hline Porosity [decimal] & Normal & 0.49 & 0.55 & 0.61 & Based on geotechnical borehole $6404 / 5$ GB1. \\
\hline Gas Saturation [decimal] & StrBeta & 0.025 & 0.071 & 0.21 & $\begin{array}{l}\text { Based on Bünz et al 2005, Westbrook et al } 2008 \text { and Faverola } \\
\text { et al } 2009 .\end{array}$ \\
\hline Gas Expans. Factor (1/Bg) [Sm3/m3] & Constant & 164 & 164 & 164 & Based on Sloan \& Koh 2008. \\
\hline
\end{tabular}

\begin{tabular}{|c|c|c|c|c|c|}
\hline Parameter [units] & \multicolumn{5}{|c|}{ Free gas zone } \\
\hline Area of Closure [km2] & StrBeta & 1070 & 2254 & 3120 & $\begin{array}{l}\text { Mid case: BSR outline without "tricky" zones, Low case: "Sweet } \\
\text { spot" BSR outline, High case: BSR outline. }\end{array}$ \\
\hline Column Height [m] & StrBeta & 20 & 40 & 80 & $\begin{array}{l}\text { Based on Bünz et al 2005, Westbrook et al } 2008 \text { and Faverola } \\
\text { et al } 2009 \text {. }\end{array}$ \\
\hline Net/Gross Ratio [decimal] & Normal & 0.001 & 0.5 & 1 & Based on Hustoft et al 2007 \& Bouriak et al 2003. \\
\hline Porosity [decimal] & Normal & 0.49 & 0.55 & 0.61 & Based on geotechnical borehole $6404 / 5$ GB1. \\
\hline Gas Saturation [decimal] & StrBeta & 0.002 & 0.007 & 0.19 & $\begin{array}{l}\text { Based on Bünz et al 2005, Westbrook et al } 2008 \text { and Faverola } \\
\text { et al } 2009 \text {. }\end{array}$ \\
\hline Gas Expans. Factor (1/Bg) [Sm3/m3] & Normal & 100 & 120 & 140 & Assumed to be $1 /$ pressure, with a reservoir depth of $1200 \mathrm{~m}$. \\
\hline
\end{tabular}

\begin{tabular}{|c|c|c|c|c|c|}
\hline Parameter [units] & $\begin{array}{l}\text { Chimney } \\
\text { Type }\end{array}$ & Min & Base & Max & \\
\hline Gross Rock Volume [km2-m] & Normal & 3452 & 9286 & 15120 & $\begin{array}{l}\text { Weibull (2008) for direct estimate for low case, extrapolated } \\
\text { across the Nyegga prospect in the high case. }\end{array}$ \\
\hline Net/Gross Ratio [decimal] & Normal & 0.001 & 0.5 & 1 & $\begin{array}{l}\text { Uncertainty with respect to suitable host rock, assumed to be } \\
50: 50 \text { chance. }\end{array}$ \\
\hline Porosity [decimal] & Normal & 0.35 & 0.55 & 0.75 & $\begin{array}{l}\text { Mean value from geotech borehole, wider range to account for } \\
\text { carbonate formation and fracture-induced porosity. }\end{array}$ \\
\hline Gas Saturation [decimal] & Normal & 0.05 & 0.2 & 0.35 & $\begin{array}{l}\text { Increased to reflect hydrate potential. Max case based on Stoian } \\
\text { et al (2008) example from offshore Korea. }\end{array}$ \\
\hline Gas Expans. Factor (1/Bg) [Sm3/m3] & Constant & 164 & 164 & 164 & Based on Sloan \& Koh 2008. \\
\hline
\end{tabular}

The large uncertainty in the reservoir parameters is accounted for by using stochastic models with a range of parameters. Stochastic models, based on the Monte Carlo method, were set up to handle the parameter ranges described above. Its 5000 realizations calculated a probabilistic range based on a random element constrained within the range of input parameters assigned previously. This approach is deemed the most optimal for dealing with the high degree of uncertainty involved in this first-order estimation.

Statistically the base case equates to the mode, while both the P50 and mean cases may be offset due to the skewed distributions used. Percentiles, such as P1, P50 and P99, relate to probabilities of a reservoir parameter being present with the respective quality. Reservoir parameters are given using the "minimum-base-maximum" value convention. As an example, the 10-50-120 distribution for the 
thickness of the hydrate zone gives a $99 \%$ probability of a hydrate zone at least $10 \mathrm{~m}$ thick being present, yet only a $1 \%$ chance that a $120 \mathrm{~m}$ thick zone is present in any of the 5000 realizations calculated. The shape of the distribution, either Normal or Stretched Beta, then defines which thickness is most likely to be chosen in the calculation (Figure 7).

Figure 7. A graphical representation of the distributions of the various reservoir parameters for Nyegga's three segments. The graphs illustrate the relative probability of a particular value to be chosen for the stochastic volumetric calculation. The peak of the curve, corresponding to the mode, stands a higher chance of being selected than the outlying points near the P99 and P1 end points. Skewed distributions are used particularly for the gas hydrate saturation parameter in order to account for both the relatively large upside potential while keeping a conservative P99 and base case. Please note that the y-axis is a measure of the probability of the respective reservoir parameter value being chosen in any particular stochastic calculation run. Please note the different $\mathrm{x}$-axis scales for each diagram. For clarity, distribution ranges are tabulated in Table 1.

\section{Gas hydrate zone}
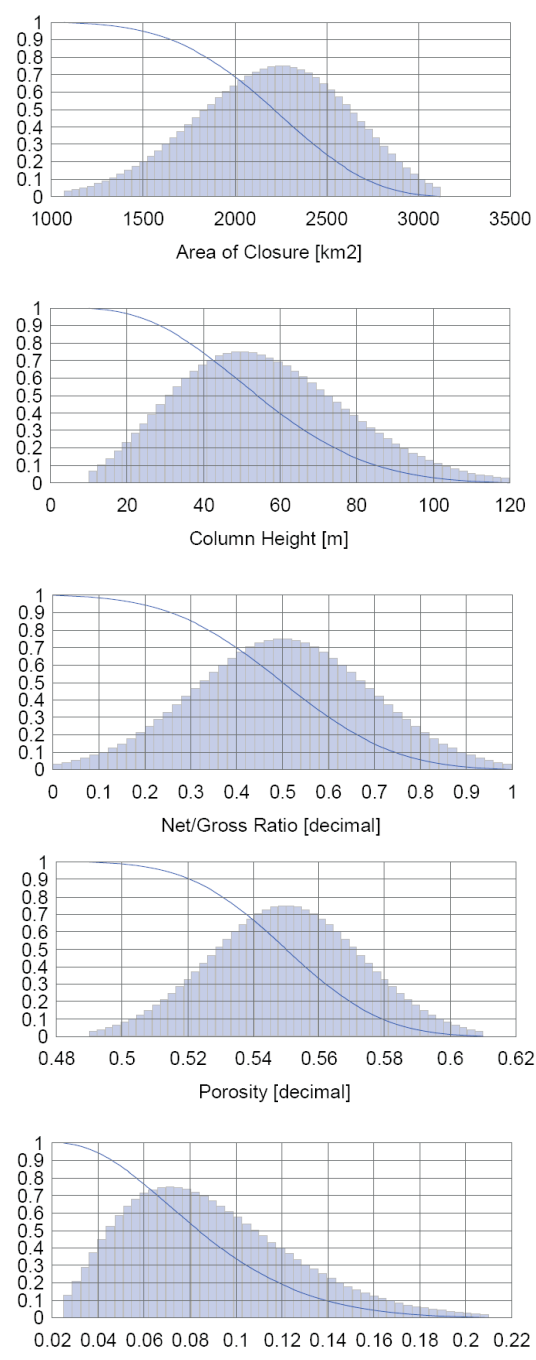

Gas Saturation [decimal]
Free gas zone
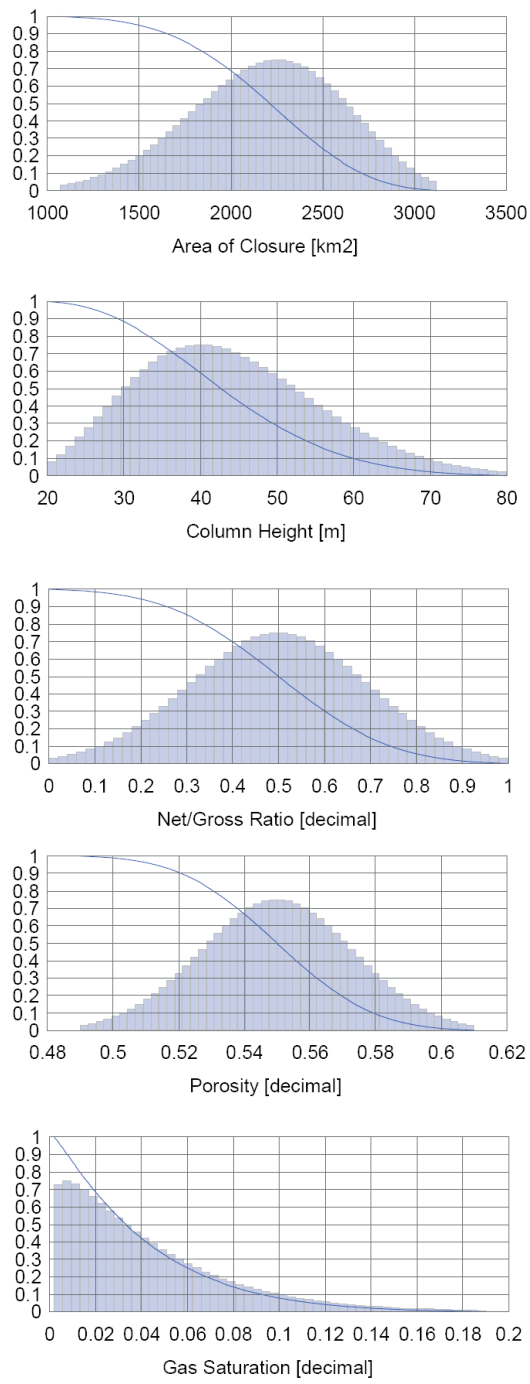

\section{Chimney zone}
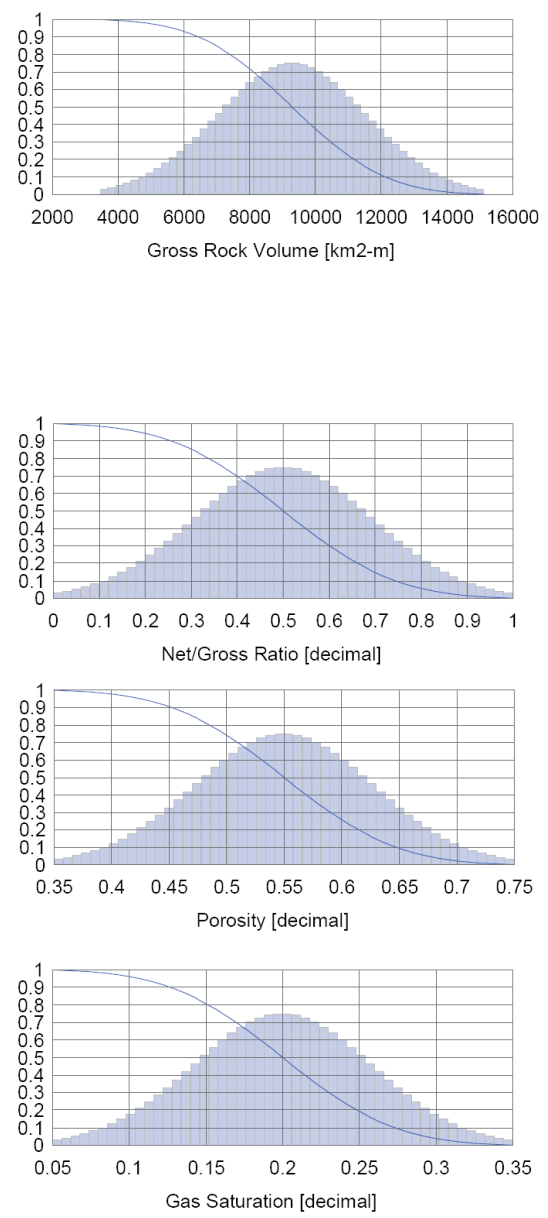
Seismic interpretation, primarily on the JMF97 2D survey, provided the initial spatial constraint by outlining the extent of the BSR. Estimates of the thicknesses (column height, see Figure 8 and Table 2) of both the gas hydrate and free gas zone were based on OBS studies [56-58], as were the gas hydrate and free gas saturations. For the chimney zone, a GRV was calculated based on the chimney study of Weibull [60] extrapolated across the Nyegga prospect. "Traditional" reservoir parameters such as porosity are based on the geotechnical borehole 6404/5 GB1.

\subsubsection{Area of Closure}

Spatially, the reservoir is restricted to the BSR-defined lateral extent of the Nyegga prospect. The low case is defined by the interpretation of the central part of the BSR, the so-called "BSR Sweet Spot". For the high case, previous BSR interpretations were used [62]. The base case is based on the same interpretation, but disregards the zones of uncertain BSR interpretations to the north and south-east.

An upside potential exists in other areas where BSRs have been identified. Seven other areas with BSRs have been mapped in the immediate area around the main Nyegga prospect [62], with a combined area of $658 \mathrm{~km}^{2}$. These areas, as well as other hydrate-prone zones on the Norwegian continental shelf, have not been included in the volumetric calculation but represent a considerable upside potential.

\subsubsection{Column Height}

The thicknesses and gas hydrate saturation of the hydrate system itself, both the solid hydrate-layer and the underlying free gas, is primarily defined by the OBS experiments of Bünz et al. [56], Westbrook et al. [58] and Faverola et al. [63].

Utilising P-wave velocities derived from the OBS experiments as interval velocities, it is possible to derive a time-depth relationship at the OBS stations.

This allows the OBS-derived P-wave velocities to be plotted directly onto the seismic profiles (Figure 9), serving both as a quality-control and for visualising the continuity of the various zones of anomalous velocities. Furthermore, a time-depth relationship allows the plotting of time-domain interpreted horizons onto the OBS depth-domain "well section" (Figure 8).

Table 2. Summary of the column height and saturation values derived from the 6404/5 GB1 borehole as well as the OBS sites of Bünz et al. [56], Westbrook et al. [58] and Faverola et al. [63].

\begin{tabular}{|c|c|c|c|c|c|c|c|c|}
\hline Station & $\begin{array}{c}\text { Water } \\
\text { depth }(\mathrm{m})\end{array}$ & $\begin{array}{l}\text { Depth to } \\
\text { BSR (mbsl) }\end{array}$ & $\begin{array}{l}\text { Hydrate } \\
\text { zone }\end{array}$ & $\begin{array}{l}\text { Free gas } \\
\text { thickness }\end{array}$ & $\begin{array}{l}\text { Hydrate } \\
\text { saturation }\end{array}$ & $\begin{array}{l}\text { Free gas } \\
\text { saturation }\end{array}$ & Comments & Reference \\
\hline $6404 / 5$ GB1 & 960 & 1220 & 25 & 15 to $>40$ & $?$ & $?$ & $\begin{array}{l}\text { Free gas zone poorly imaged by borehole ending } 50 \mathrm{~m} \text { below } \\
\text { the BSR }\end{array}$ & 6404/5 GB1 borehole \\
\hline OBS 758 & & 1052 & $\max 120$ & $18 \mathrm{~m}$ & $12-20 \%$ & & $\begin{array}{l}\text { Two additional gas layers at } 1128 \text { (30m thick) and } 1415(35 \mathrm{~m} \\
\text { thick) }\end{array}$ & Westbrook et al 2008 \\
\hline $\begin{array}{l}\text { JM516 } \\
\text { JM517 }\end{array}$ & $\begin{array}{l}965 \\
945\end{array}$ & $\begin{array}{l}1245 \\
1225\end{array}$ & $\begin{array}{l}47 \\
56\end{array}$ & $46-90$ & $\begin{array}{r}6-12 \% \\
11-21 \%\end{array}$ & $\begin{array}{l}0.7-14 \% \\
0.9-19 \%\end{array}$ & Low hydrate estimate $=$ hydrate in frame, high-estimate $=$ & \multirow{3}{*}{ Bünz et al 2005} \\
\hline JM523 & 921 & 1201 & 42 & $50-85$ & $4-8 \%$ & $0.9-18 \%$ & $\begin{array}{l}\text { hydrate as pore fill. Low gas estımate = homogeneous } \\
\text { distribution, high gas estimate = patchy distribution. }\end{array}$ & \\
\hline JM524 & 919 & 1199 & 32 & $60-68$ & $2.5-5 \%$ & $0.7-14 \%$ & & \\
\hline $1 Z$ & 708 & 956 & 70 & 37 & & $0.55-15 \%$ & & \multirow{5}{*}{ Faverola et al 2009} \\
\hline $3 \mathrm{H}$ & 740 & 998 & 71 & 29 & & $0.5-14 \%$ & & \\
\hline $4 Z$ & 706 & no BSR & & & & & Gas trapped beneath GDF, $0.3-8 \%$ & \\
\hline $5 Z$ & 733 & no BSR & & & & & Gas trapped beneath GDF, 0.2-5.5\% & \\
\hline $6 \mathrm{H}$ & 765 & no BSR & & & & & No LVZ1 seen on OBS data & \\
\hline GeoX input & & & $10-50-120$ & $0-40-80$ & $2.5-7.1-21$ & $.2-0.7-19$ & & \\
\hline
\end{tabular}


Figure 8. Summary of ocean-bottom seismic (OBS) data of Bünz et al. [56], Westbrook et al. [58] and Faverola et al. [63] compared to the 6404/5 GB1 measured P-wave velocity. The bottom simulating reflection (BSR) well top is defined on the basis of the onset of the low velocity anomaly on the OBS data, and is notably absent at stations $4 \mathrm{Z}, 5 \mathrm{Z}$ and $6 \mathrm{H}$. The remaining tops are defined by the intersection of the interpreted horizons with the "well path" of the OBS stations. Note that GDF $=$ glacigenic debris flow.

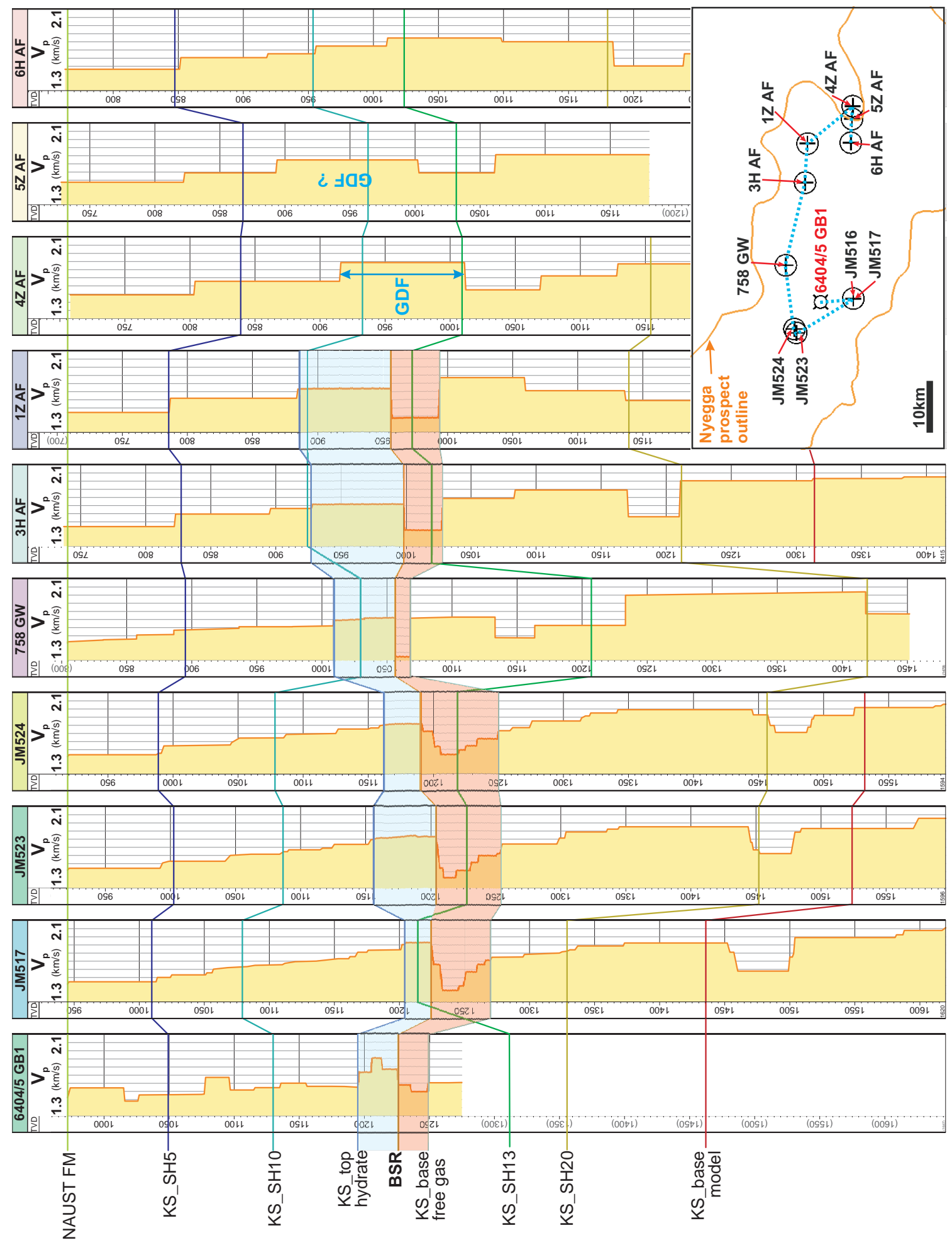


Figure 9. OBS-derived P-wave velocities as displayed on a composite seismic line. The illustration also provides an overview of the interpreted horizons. Note particularly the cross-cutting nature of the bottom simulating reflection (BSR). Furthermore, the $\mathrm{P}$-wave velocity at $\mathrm{OBS}$ station $6 \mathrm{H}$ indicates no free gas layer at the expected BSR layer, leading to the reduction of the BSR-extent of Bünz et al. [62] in the volume calculation. Well tops are based on the OBS data. OBS data from Bünz et al. [56], Westbrook et al. [58] and Faverola et al. [63].

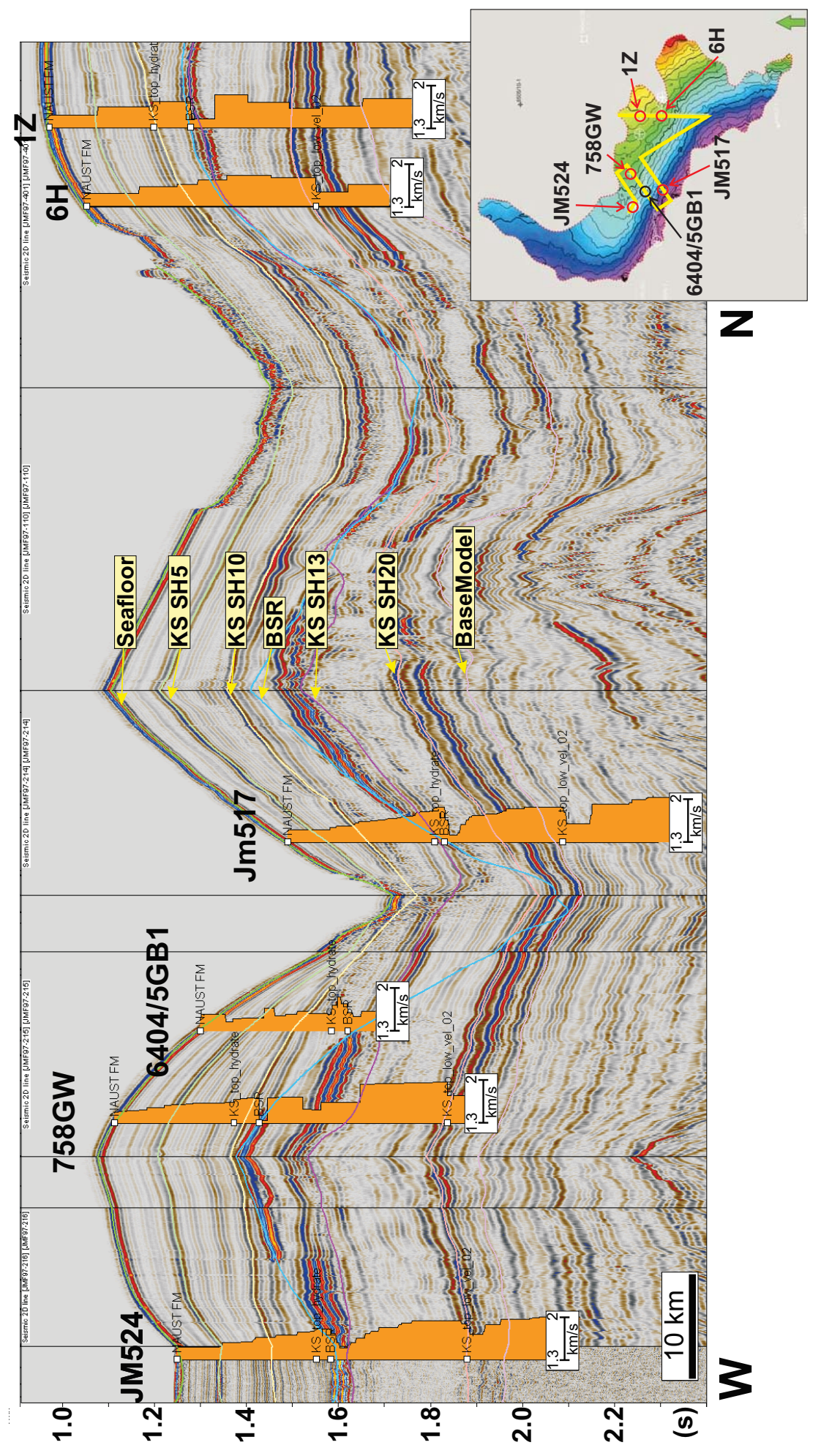




\subsubsection{Porosity}

Porosity was measured at the nearby geotechnical borehole 6404/5-GB1 (Figure 10), and is restricted to a narrow distribution of $\mathbf{0 . 4 9 - 0 . 5 5 - 0 . 6 1}$.

Figure 10. Wireline and measured data from the 6404/GB5 geotechnical borehole. Unfortunately, poor data quality makes the wireline data of limited use. The porosity measurements (5th track), however, are useful and provide constraints for the reservoir. Vertical seismic profiling (VSP), shown in the 6th track, appears to indicate a slightly higher velocity in a $30 \mathrm{~m}$ interval above the BSR, a zone that has been interpreted as the solid gas hydrate zone. Porosity and unit weight were measured twice, once offshore and once onshore. Plotting them on the same track does not reveal major differences in the trends. Data is provided by Statoil, and is the property of the Norwegian Deepwater Programme $[64,65]$. Wireline logs are digitalised by hand and inaccuracies need to be considered.

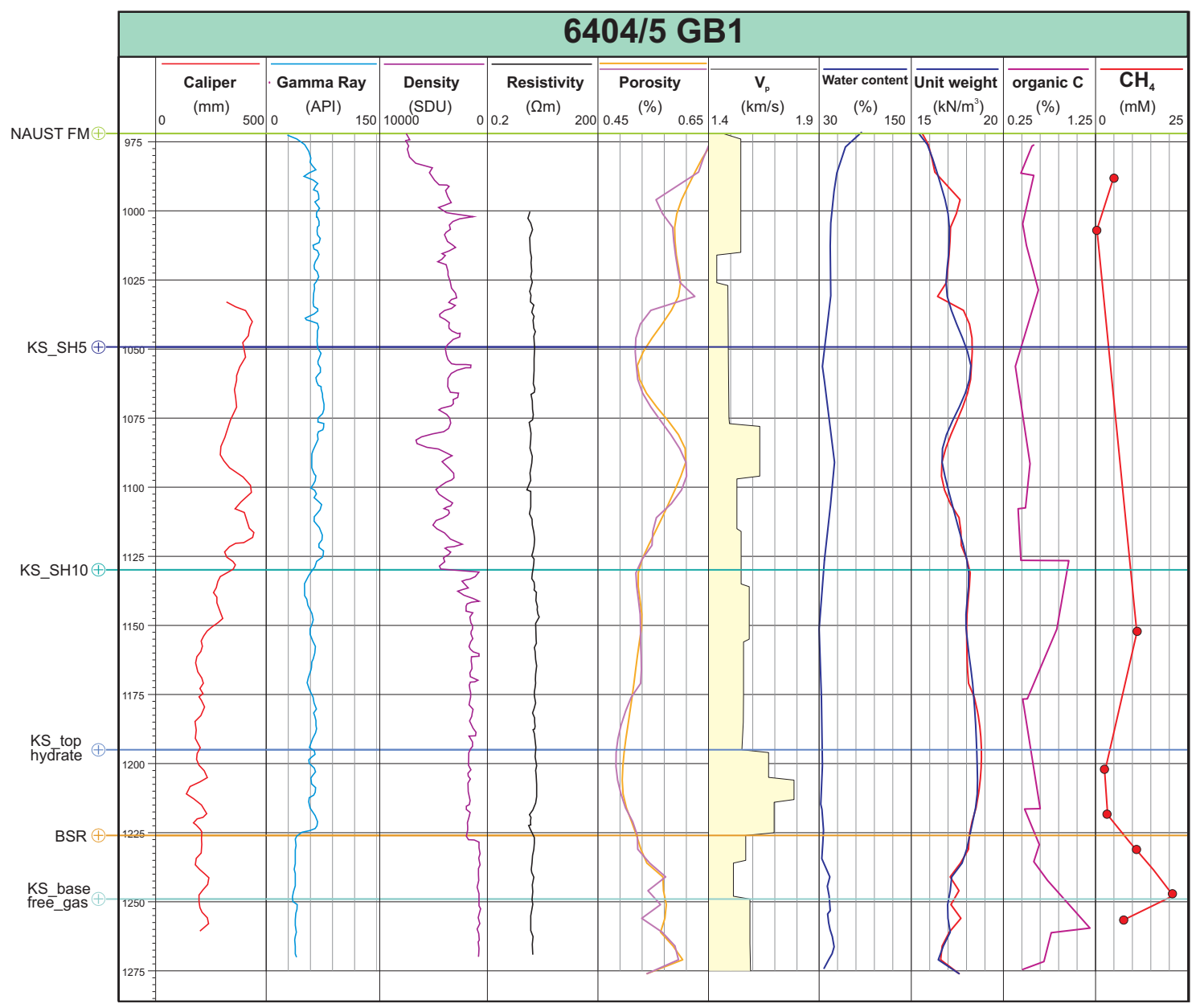

For the chimney zone, porosity is assigned a broader range centered upon the same base case, namely 0.35-0.55-0.75. This range is designed to account for the possibility of increased authigenic carbonate formation lowering the porosity, particularly in the uppermost chimney zones. On the other hand, increased fracture porosity could be generated by increased fluid flux. 


\subsubsection{Net to Gross}

Hustoft et al. [55] illustrate a series of porous and permeable zones suitable for hydrate formation. A quick estimate suggest that this "reservoir" accounts for approximately $50 \%$ of the area of interest. A wide NTG range of $\mathbf{0 - 1}$ is thus used to account for the large uncertainty due to limited ground truth.

\subsubsection{Gas Expansion Factor}

Gas compressibility is defined by the relative amount of hydrate-bound gas compared to the same gas at standard P-T conditions. The base case assumes full cage occupancy, with 164 units of methane held within one unit of hydrate [2]. A constant value of $\mathbf{1 6 4}$ is thus used for the gas hydrate zone.

For the free gas zone, compressibility is assumed to be 1/pressure. Given that the prospect lies only a few hundred meters beneath the seafloor at approximately $1200 \mathrm{~m}$ depth, and assuming hydrostatic pressure, a gas expansion factor range of 100-120-140 was used.

\subsubsection{Gas Hydrate Saturation}

\subsubsection{Hydrate and Free Gas Zone}

As summarized by Table 2, both the gas hydrate saturation and the free gas saturation at the Nyegga prospect are low, on the order of $1-2 \%$ of the pore space. This is similar to other Class 4 hydrate reservoirs, as the $<1 \%$ saturation reported from the Cascadia margin by Milkov et al. [66]. At Cascadia, Riedel et al. [35] outline four essentially independent methods for estimating the hydrate saturation, yet still come up with a large uncertainty of $<5 \%$ to $>25 \%$ of gas hydrate saturation. Similar saturations have been obtained through a multi-channel seismic analysis at the Korean Ulleung Basin, where Stoian [67] calculated a 1-4\% gas hydrate saturation.

Even for well studied hydrate deposits where ground truth is available, gas hydrate saturations vary widely. As an example, Ruppel et al. [32] outline Gulf of Mexico gas hydrate saturations of 1.5-6\%, $1-12 \%$ and $>20 \%$ depending on which method for calculation is used [68-70].

At the Nyegga prospect, depending on the model of hydrate formation used, a heterogeneous gas hydrate saturation of up to 10-20\% was calculated by Bünz et al. [56]. Gas hydrate saturation of up to $12 \%$ were predicted using a frame-only model, while gas hydrate saturation of up to $20 \%$ were predicted for the frame-and-pore model [58].

With this uncertainty in mind, a broad yet conservative gas hydrate saturation range from $\mathbf{0 . 0 2 5}$ (P99) to $\mathbf{0 . 0 7 1}$ (mode) to $\mathbf{0 . 2 1}$ (P1) for the hydrate zone was used. A free gas saturation from $\mathbf{0 . 0 0 2}$ (P99) to $\mathbf{0 . 0 0 7}$ (mode) to $\mathbf{0 . 1 9}(\mathrm{P} 1)$ is assigned for the free gas zone.

High values of $\mathbf{0 . 2 1}$ and $\mathbf{0 . 1 8}$ are deemed to represent possible "sweet spots" where high and focused fluid flux forms higher saturation hydrate deposits.

\subsubsection{Chimney Structures}

Chimney structures are expected to contain higher saturations of gas hydrates than the hydrate zone, due to the focused fluid flux thought to form them. Chimney structures typically lie below complex 
pockmarks [38]. Furthermore, such complex pockmarks are the only locations where solid gas hydrates have been inferred at shallow depth [51] and subsequently sampled with gravity corers [52,71]. The pockmark-chimney interaction is further outlined by Hustoft et al. [72].

It follows that the Nyegga chimney structures have been assigned a more optimistic hydrate saturation range of $\mathbf{0 . 0 5 - 0 . 2 - 0 . 3 5}$. To account for the uncertainty in whether the chimneys actually contain hydrate, as raised by Paull et al. [61], cases were calculated without the chimney component. The chimney zone hydrate is thus considered an upside of the Nyegga prospect.

\section{Results}

Volumes of in-place gas, even in the most pessimistic P90 case, amount to $151-183 \mathrm{GSm}^{3}$, depending on whether the chimney zone is included or not. Out of the three segments, the gas hydrate zone contains the majority of resources ( $69 \%$ of the total mean case), followed by the free gas zone (19\%) and the chimney zone (12\%, Table 3$)$.

Table 3. Results of in-place volumes of hydrate-bound methane at Nyegga. Intermediate volumes are given for comparison. To calculate the deterministic volume, only the base case reservoir parameters were used. In contrast, wide distributions were used to generate the stochastic spread.

\begin{tabular}{|c|c|c|c|c|c|c|}
\hline \multirow{3}{*}{$\begin{array}{l}\text { Gas hydrate zone } \\
\text { Gross rock volume }\end{array}$} & \multicolumn{2}{|c|}{ Deterministic } & \multicolumn{4}{|c|}{ Stochastic } \\
\hline & unit & & Mean & $P 90$ & P50 & $P 10$ \\
\hline & $\mathrm{GSm}^{3}$ & 112.7 & 122.1 & 57.3 & 115.3 & 195.9 \\
\hline Net rock volume & $\mathrm{GSm}^{3}$ & 56.4 & 60.9 & 21.0 & 54.3 & 109.3 \\
\hline HC pore volume & $\mathrm{GSm}^{3}$ & 2.2 & 3.0 & 0.8 & 2.4 & 5.9 \\
\hline Gas initially in place (GIIP) & $\mathrm{GSm}^{3}$ & 361.2 & 489.8 & 133.5 & 398.7 & 967.5 \\
\hline \multicolumn{7}{|l|}{ Free gas zone } \\
\hline Gross rock volume & $\mathrm{GSm}^{3}$ & 90.2 & 95.3 & 57.7 & 91.6 & 138.9 \\
\hline Net rock volume & $\mathrm{GSm}^{3}$ & 45.1 & 47.4 & 19.4 & 43.7 & 80.4 \\
\hline HC pore volume & $\mathrm{GSm}^{3}$ & 0.2 & 1.1 & 0.1 & 0.7 & 2.7 \\
\hline Gas initially in place (GIIP) & $\mathrm{GSm}^{3}$ & 20.8 & 134.7 & 17.4 & 89.4 & 313.6 \\
\hline \multicolumn{7}{|l|}{ Chimney zone } \\
\hline Gross rock volume & $\mathrm{GSm}^{3}$ & 9.3 & 9.3 & 6.4 & 9.3 & 12.1 \\
\hline Net rock volume & $\mathrm{GSm}^{3}$ & 4.6 & 4.7 & 2.2 & 4.5 & 7.5 \\
\hline HC pore volume & $\mathrm{GSm}^{3}$ & 0.5 & 0.5 & 0.2 & 0.5 & 0.9 \\
\hline Gas initially in place (GIIP) & $\mathrm{GSm}^{3}$ & 83.8 & 85.4 & 32.5 & 77.2 & 149.8 \\
\hline \multicolumn{7}{|l|}{ Nyegga without chimneys } \\
\hline \multirow{2}{*}{ Gas initially in place (GIIP) } & $\mathrm{GSm}^{3}$ & 382.0 & 624.5 & 150.9 & 488.1 & 1281.1 \\
\hline & tcf & 13.5 & 22.1 & 5.3 & 17.2 & 45.2 \\
\hline \multicolumn{7}{|l|}{ Nyegga total (all 3 segments) } \\
\hline \multirow{2}{*}{ Gas initially in place (GIIP) } & $\mathrm{GSm}^{3}$ & 465.8 & 709.9 & 183.4 & 565.3 & 1430.9 \\
\hline & tcf & 16.4 & 25.1 & 6.5 & 20.0 & 50.5 \\
\hline
\end{tabular}

Please note $\mathrm{GSm}^{3}=10^{9}$ standard cubic metres, $t c f=10^{12}$ standard cubic feet 
As the volumes already indicated, the gas hydrate and free gas zones seem to be the most important constituents of the prospect. This is also obvious from the variance diagram (Figure 11), where the parameters assigned to the aforementioned zones dominate. The variance is quite simply a measure of statistical dispersion, and illustrates the parameters with the largest spread that contribute the most to the final result.

Figure 11. A variance diagram showing the relative importance of the various reservoir parameters on the result. Note the dominance of the uncertainty related to the gas hydrate zone, particularly gas hydrate saturation, the column height of the gas hydrate zone and the net to gross ratio.

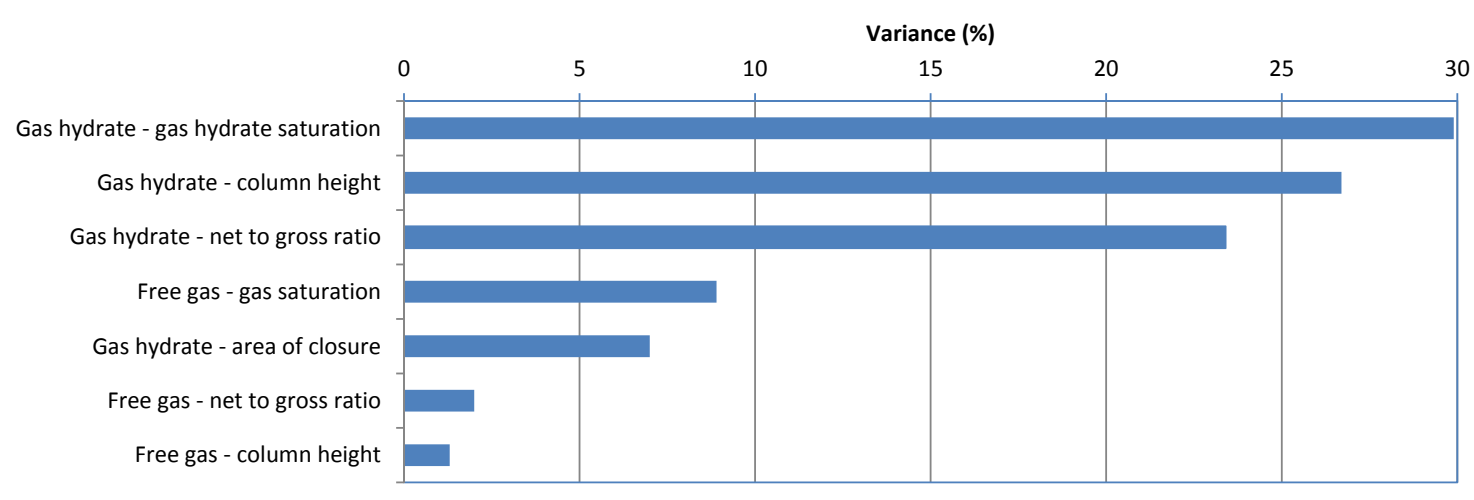

\section{Discussion}

Regional hydrate assessments have been conducted in a wide range of settings. In the marine environment, most of these were based on the delineation of the bottom simulating reflection (BSR) and subsequent extrapolation of poorly constrained reservoir parameters across the area. To ease comparison between very different hydrate provinces, a resource density was calculated based on the reported in-place resources and the areal extent of the BSR (Table 4, Figure 12). The range of those, from $0.005 \mathrm{GSm}^{3} / \mathrm{km}^{2}$ to $2.129 \mathrm{GSm}^{3} / \mathrm{km}^{2}$, represents both the uncertainty range with estimating hydrate-bound volumes and the geological differences between these provinces. On the one side, $0.005 \mathrm{GSm}^{3} / \mathrm{km}^{2}$ resembles the average methane hydrate resource density extrapolated across the whole Earth landmass. On the other side, $2.129 \mathrm{GSm}^{3} / \mathrm{km}^{2}$ is a reasonable resource density seen in Norwegian conventional gas fields.

The Nyegga prospect, with a range of $0.08 \mathrm{GSm}^{3} / \mathrm{km}^{2}$ to $0.64 \mathrm{GSm} / \mathrm{km}^{2}$, plots in between these two end-members. In terms of its areal extent, it is a fraction of the other hydrate provinces, most closely related to the West Svalbard margin investigated by Hustoft et al. [73]. Its mean resource density $\left(0.32 \mathrm{GSm}^{3} / \mathrm{km}^{2}\right)$ is comparable to both the West Svalbard site $\left(0.35 \mathrm{GSm}^{3} / \mathrm{km}^{2}\right.$, Hustoft et al. [73]) and the Nankai Trough $\left(0.23 \mathrm{GSm}^{3} / \mathrm{km}^{2}\right.$, Ichikawa and Yonezawa [30]). Nyegga's low case, $0.08 \mathrm{GSm}^{3} / \mathrm{km}^{2}$, nonetheless resembles the resource density calculated for the whole ocean (0.06 GSm $3{ }^{3} / \mathrm{km}^{2}$, MacDonald [74]). Compared to geologically similar provinces, distinguished by large areas of low saturations, Nyegga seems to have a slightly higher resource density than the regional Gulf of Mexico site, yet a lower resource density than both the Blake Ridge and New Zealand's Fiordland and Hikurangi provinces. 
Comparing the recent investigations of the marine Gulf of Mexico $\left(1.33 \mathrm{GSm}^{3} / \mathrm{km}^{2}\right.$ in the mean case) system by the Minerals Management Service [33] to the assessment of the Alaskan North Slope $\left(0.02 \mathrm{GSm}^{3} / \mathrm{km}^{2}\right.$ in the mean case) by the USGS [25] highlights the general difference of the permafrost deposits compared to the marine provinces. Nonetheless, production tests are being undertaken on permafrost hydrate, where easier logistics and a well developed infrastructure make such projects economically feasible. The relatively low resource density at the Alaskan North Slope permafrost province, highlights the inadequacy of using the resource density as the sole indicator of future development. While the overall resource density appears to be low on the Alaskan North Slope, its sweet-spot deposits, onshore location and proximity to conventional petroleum infrastructure is likely to make the North Slope an early candidate for commercial production.

In absolute value, the GIIP numbers of approximately 625 to $715 \mathrm{GSm}^{3}$, depending on whether the chimney segment is included, are higher than the originally in-place resource of the conventional Ormen Lange gas field (439 GSm ${ }^{3}$ NPD [75]). However, when compared to the area it covers the Nyegga prospect has a considerably lower in-place resource density $\left(0.32 \mathrm{GSm}^{3} / \mathrm{km}^{2}\right.$, Table 4$)$ compared to the mega-field Troll $\left(3.4 \mathrm{GSm}^{3} / \mathrm{km}^{2}\right)$, the high-pressure, high-temperature field Kristin $\left(1.24 \mathrm{GSm}^{3} / \mathrm{km}^{2}\right)$ and Ormen Lange $\left(1.3 \mathrm{GSm}^{3} / \mathrm{km}^{2}\right.$, NPD [76]). The only discovery on the Norwegian continental shelf with a comparable energy per unit area density is Peon, whose $35 \mathrm{GSm}^{3}$ in-place resources are spread over $80 \mathrm{~km}^{2}\left(0.44 \mathrm{GSm}^{3} / \mathrm{km}^{2}\right)$ [76,77].

Table 4. Comparison of the resource density at the Nyegga prospect and other hydrate and conventional deposits worldwide. Note that permafrost hydrate provinces are denoted with italics. Data from this study, Collett et al. [25], Collett [26], Ichikawa and Yonezawa [30], Frye [33], Hustoft et al. [73], MacDonald [74], Milkov and Sassen [78], Pecher et al. [79], Laberg et al. [80], Hovland et al. [81], Milkov and Sassen [82], Lodolo et al. [83], Fohrmann [84], Gorman [85] and NPD [76]. For ease of comparison, the data presented here is also plotted in Figure 12.

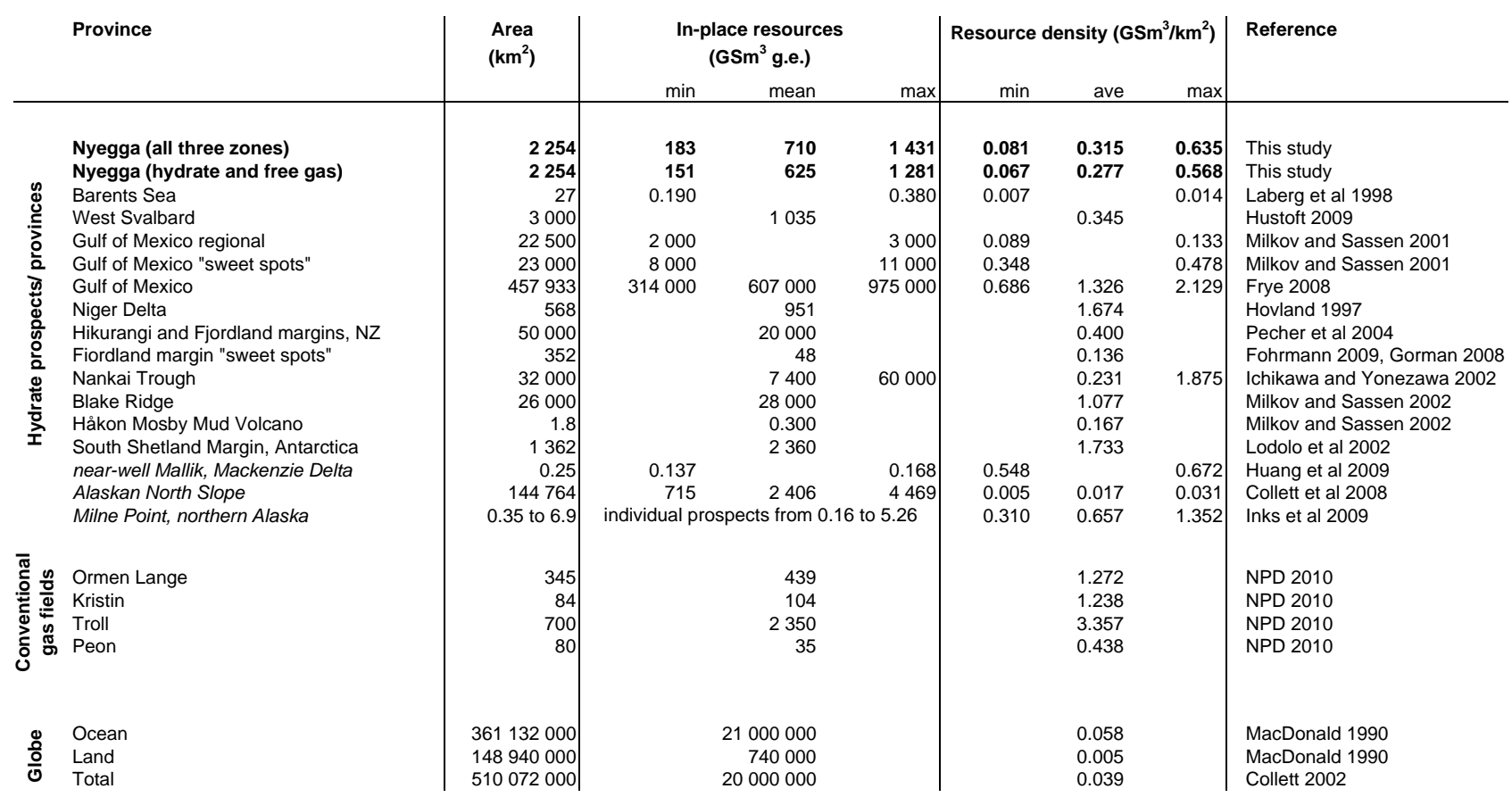


Figure 12. Graphical comparison of the resource density at the Nyegga prospect and other hydrate and conventional deposits worldwide. The diamonds indicate the average resource density, while the minimum and maximum resource densities are represented by triangles and circles, respectively. Data source identical to Table 4. Please note the logarithmic x-axis.

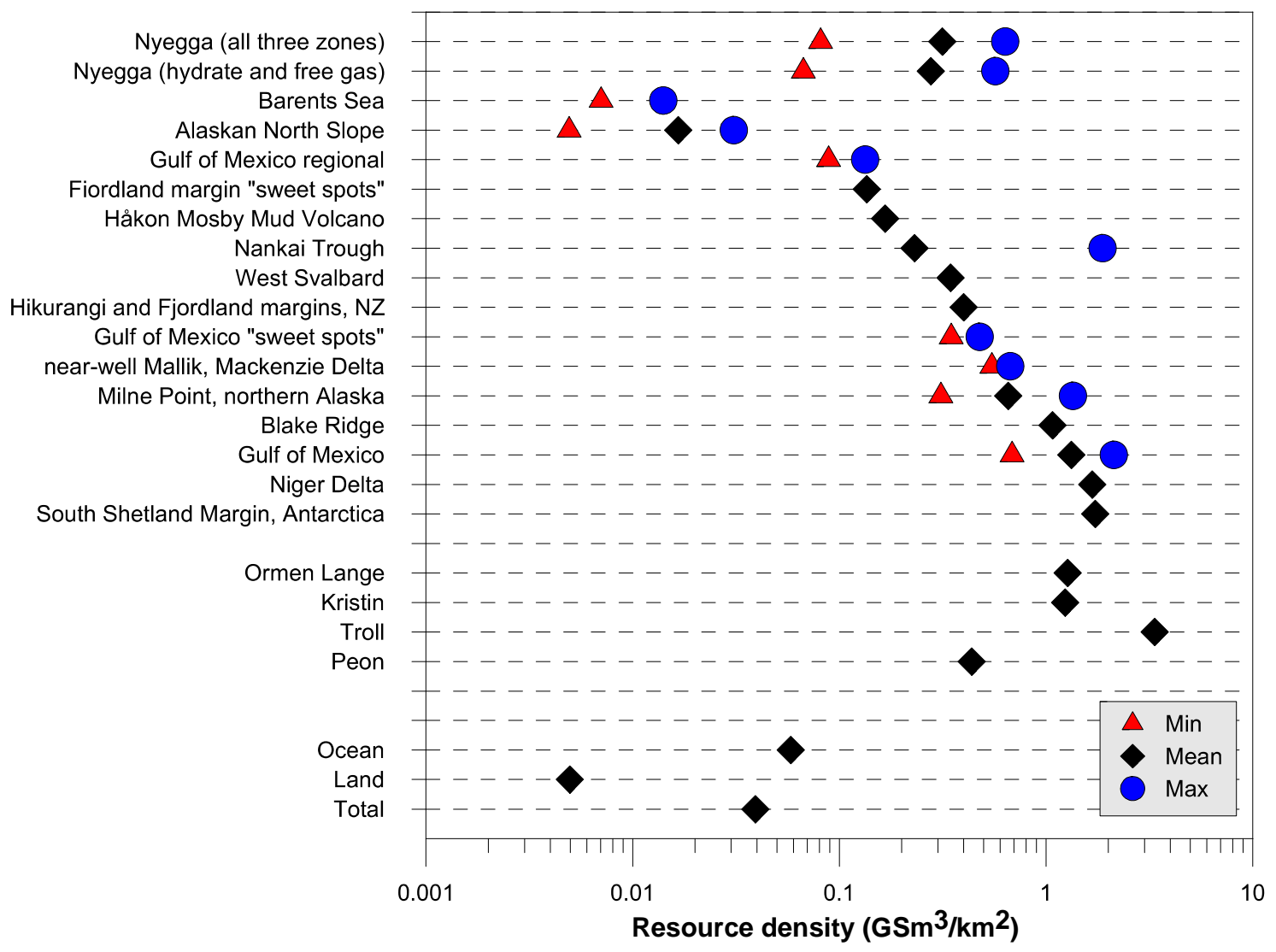

In summary, the resource density at Nyegga is comparable to other hydrate provinces. Furthermore, the large spread of calculated resources at both Nyegga and other hydrate provinces illustrates the large uncertainty involved in quantifying gas hydrate deposits. Nonetheless, stochastic modelling as employed in this study is critical to constrain the range of probable in-place volumes at any given prospect.

\section{Conclusions}

- A gas hydrate prospect is defined in the Norwegian Sea.

- The gas hydrate resource, $710 \mathrm{GSm}^{3}$ in the mean case, appears to be significant for a prospect on the Norwegian Continental Margin.

- Large uncertainty in calculated in-place volumes exists, primarily due to the lateral variations in reservoir parameters (3D reservoir extent and gas hydrate saturation being the most important).

- Using the employed reservoir parameters, it appears that the gas hydrate and free gas zones contribute most to the total in-place resources. Chimneys, assuming that they are at least partially hydrate-filled, contribute to localized high saturation hydrate accumulations.

- The resource density of the Nyegga prospect, $0.32 \mathrm{GSm}^{3} / \mathrm{km}^{2}$, is generally in line with that calculated for other hydrate provinces, though the large spread of the estimates emphasizes the large uncertainties involved. 
- Apart from their economic value, the hydrate-held methane could, under changing P-T conditions, potentially be released into the ocean and/or the atmosphere. Further work is required to test this hypothesis.

- Further work is required to determine the producibility of this resource. A hydrate-specific simulator could, for example, assist in quantifying potential recovery factors.

- It is questionable whether the Nyegga resource will ever be commercially produced, given its low saturation and large lateral extent. At the very least, a hydrate-specific reservoir simulator needs to be employed in a feasibility study.

\section{Acknowledgements}

This study was conducted as part of an MSc at the University of Troms $\varnothing$. Bayerngas Norge AS, the SEABED consortium, Statoil and Fugro Geos provided parts of the data used. Bayerngas Norge AS is further acknowledged with generous financial, technical and moral support that made this study possible during Kim Senger's employment period. Geoknowledge AS provided access to the GeoX software. Finally, the authors would like to thank four anonymous reviewers for their constructive comments that have improved this manuscript.

\section{References}

1. Kvenvolden, K.A. Potential effects of gas hydrate on human welfare. PNAS 1999, 96, 3420-3426.

2. Sloan, E.D.; Koh, C. Clathrate Hydrates of Natural Gases (Chemical Industries Series), 3rd ed.; CRC Press: Boca Raton, FL, USA, 2008; p. 721.

3. Hammerschmidt, E. Formation of Gas Hydrates in Natural Transmission Lines. Ind. Eng. Chem. 1934, 26, 851-855.

4. Sloan, E.D. Seven Industrial Hydrate Flow Assurance Lessons from 1993-2003; Technical Report for Centre of Hydrate Research: Golden, CO, USA, 2003.

5. Makogon, Y.; Holditch, S.; Makogon, T. Proven reserves and basics for development of gas hydrate deposits. In Proceedings of the AAPG Hedberg Conference, Vancouver, Canada, 2004; p. 3.

6. Sultan, N.; Cochonat, P.; Foucher, J.P.; Mienert, J. Effect of gas hydrates melting on seafloor slope instability. Mar. Geol. 2004, 213, 379-401.

7. Peters, D.; Hatton, G.; Mehta, A.; Hadley, C. Gas hydrate geohazards in shallow sediments and their impact on the design of subsea systems. In Proceedings of the 6th International Conference on Gas Hydrates, Vancouver, Canada, 2008, p. 7.

8. Kennett, J.; Cannariato, K.; Hendy, I.; Behl, R. Methane Hydrates in Quaternary Climate Change: The Clathrate Gun Hypothesis; American Geophysical Union: Washington, DC, USA, 2003; Volume 54.

9. Maslin, M.; Owen, M.; Day, S.; Long, D. Linking continental-slope failures and climate change: Testing the clathrate gun hypothesis. Geology 2004, 32, 53-56.

10. Dickens, G. Climate: A Methane Trigger for Rapid Warming? Science 2003, 299, 1017.

11. Bentley, R.W. Global oil \& gas depletion: an overview. Energy Policy 2002, 30, 189-205. 
12. Holditch, S.A.; Chianelli, R.R. Factors That Will Influence Oil and Gas Supply and Demand in the 21st Century. MRS Bulletin 2008, 33, 317-325.

13. Max, M.; Johnson, A.; Dillon, W. Economic Geology of Natural Gas Hydrate, Coastal Systems and Continental Margins; Springer: Dordrecht, The Netherlands, 2006; Volume 9; p. 341.

14. Moridis, G.J.; Kowalsky, M. Depressurization-induced gas production from Class 1 and Class 2 hydrate deposits. In Proceedings of the TOUGH Symposium 2006, Lawrence Berkeley National Laboratory, Berkeley, CA, USA, May 15-17, 2006; p. 8.

15. Tang, L.G.; Xiao, R.; Huang, C.; Feng, Z.P.; Fan, S.S. Experimental Investigation of Production Behavior of Gas Hydrate under Thermal Stimulation in Unconsolidated Sediment. Energy Fuels 2005, 19, 2402-2407.

16. Sung, W.; Lee, H.; Lee, H.; Lee, C. Numerical Study for Production Performances of a Methane Hydrate Reservoir Stimulated by Inhibitor Injection. Energy Sources 2002, 24, 499-512.

17. Makogon, Y. Hydrate formation in gas bearing strata under permafrost. Gazovaya promyshlennost 1965, 5, 14-15.

18. Makogon, Y.F.; Holditch, S.A.; Makogon, T.Y. Natural gas-hydrates-A potential energy source for the 21st Century. J. Pet. Sci. Eng. 2007, 56, 14-31.

19. Singh, P.; Panda, M.; Stokes, P.J. Characterization and Quantification of the Methane Hydrate Resource Potential associated with the Barrow Gas Fields. Presented at AAPG Annual Convention and Exhibition, New Orleans, LA, USA, April 11-14, 2010.

20. Numasawa, M.; Yamamoto, K.; Yasuda, M.; Fujii, T.; Fujii, K.; Dallimore, S.R.; Wright, J.F.; Nixon, F.M.; Imasato, Y.; Cho, B.; Ikegami, T.; Sugiyama, H.; Mizuta, T.; Kurihara, M.; Masuda, Y. Objectives and operation overview of the 2007 JOGMEC/NRCAN/AURORA Mallik 2L-38 gas hydrate production test. In Proceedings of the 6th International Conference on Gas Hydrates (ICGH 2008), Vancouver, BC, Canada, July 6-10, 2008; p. 10.

21. Hancock, S.H.; Dallimore, S.R.; Collett, T.S.; Carle, D.; Weatherill, B.; Satoh, T.; Inoue, T. Overview of pressure-drawdown production-test results for the JAPEX/JNOC/GSC et al. Mallik 5L-38 gas hydrate production research well. In Scientific Results from the Mallik 2002 Gas Hydrate Production Research Well Program, Mackenzie Delta, Northwest Territories, Canada; Dallimore, S.R., Collett, T.S., Eds.; Geological Society of Canada: Ottawa, Canada, 2005; Volume 585, p. 16.

22. Moridis, G.J.; Collett, T.S. Strategies for gas production from hydrate accumulations under various geological and reservoir conditions. In Proceedings of TOUGH Symposium 2003, Berkeley, CA, USA, May 12-14, 2003; p. 8.

23. Milkov, A.V. Global estimates of hydrate-bound gas in marine sediments: How much is really out there? Earth-Sci. Rev. 2004, 66, 183-197.

24. Boswell, R.; Kleinberg, R.; Collett, T.; Frye, M. Exploration Priorities for Marine Gas Hydrate Resources. Fire Ice Newsl. 2007, Spring/Summer, 11-13.

25. Collett, T.; Agena, W.; Lee, M.; Zyrianova, M.; Bird, K.; Charpentier, T.; Houseknect, D.; Klett, T.; Pollastro, R.; Schenk, C. Assessment of Gas Hydrate Resources on the North Slope, Alaska, 2008. USGS Fact Sheet 2008, 3073, 1-4.

26. Collett, T.S. Energy Resource Potential of Natural Gas Hydrates. AAPG Bulletin 2002, 86, 1971-1992. 
27. Hancock, S.H.; Dallimore, S.R.; Collett, T.S.; Satoh, T.; Inoue, T.; Huenges, E.; Henninges, J.; Weatherill, B. Overview of thermal-stimulation production-test results for the JAPEX/JNOC/GSC et al. Mallik 5L-38 gas hydrate production research well. In Scientific Results from the Mallik 2002 Gas Hydrate Production Research Well Program, Mackenzie Delta, Northwest Territories, Canada; Dallimore, S.R., Collett, T.S., Eds.; Geological Society of Canada: Ottawa, Canada, 2005; Volume 585, p. 15.

28. Inks, T.L.; Lee, M.; Agena, W.; Taylor, D.; Collett, T.S.; Zyrianova, M.; Hunter, R. Seismic prospecting for gas-hydrate and associated free-gas prospects in the Milne Point area of northern Alaska. In Natural Gas Hydrates: Energy Resource and Associated Geologic Hazards; Collett, T.S., Johnson, A., Knapp, C., Boswell, R., Eds.; The American Association of Petroleum Geologists Hedberg Special Publication (AAPG Memoir 89): Alexandria, VA, USA, 2009.

29. Collett, T.S.; Riedel, M.; Cochran, J.R.; Boswell, R.; Kumar, P.; Sathe, A.; the NGHP Expedition 01 Scientific Party. Indian continental margin gas hydrate prospects: results of the Indian national gas hydrate program (NGHP) expedition 01. In Proceedings of the 6th International Conference on Gas Hydrates, Vancouver, Canada, 2008; p. 7.

30. Ichikawa, Y.; Yonezawa, T. The outline of the MH21 program and the RD plan of methane hydrate development system for offshore Japan. Proc. Int. Symp. Ocean Space Util. Technol. 2003, 398-404.

31. Park, K.P. Gas hydrate exploration activities in Korea. In Proceedings of the 6th International Conference on Gas Hydrates, Vancouver, Canada, 2008; p. 7.

32. Ruppel, C.; Boswell, R.; Jones, E. Scientific results from Gulf of Mexico Gas Hydrates Joint Industry Project Leg II drilling: Introduction and overview. Mar. Pet. Geol. 2008, 25, 819-829.

33. Frye, M. Preliminary Evaluation of In-Place Gas Hydrate Resources: Gulf of Mexico Outer Continental Shelf; Technical Report for U.S. Department of the Interior, Minerals Management Service, Resource Evaluation Division: Washington, DC, USA, 2008.

34. Paull, C.; Matsumoto, R. Leg 164 Overview. In Proceedings of the Ocean Drilling Programme, Scientific Results; Paull, C., Matsumoto, R., Wallace, P., Dillon, W.P., Eds.; Ocean Drilling Programme: College Station, TX, USA, 1995; Volume 164, p. 8.

35. Riedel, M.; Collett, T.; Malone, M.; the Expedition 311 Scientists. In Proceedings of the Integrated Ocean Drilling Program Volume 311 Expedition Reports Cascadia Margin Gas Hydrates; Integrated Ocean Drilling Program Management International, Inc.: Washington, DC, USA, 2005; Volume 311.

36. Sassen, R.; Joye, S.; Sweet, S.T.; DeFreitas, D.A.; Milkov, A.V.; MacDonald, I.R. Thermogenic gas hydrates and hydrocarbon gases in complex chemosynthetic communities, Gulf of Mexico continental slope. Org. Geochem. 1999, 30, 485-497.

37. Solheim, A.; Bryn, P.; Sejrup, H.; Mienert, J.; Berg, K. Ormen Lange-an integrated study for the safe development of a deep-water gas field within the Storegga Slide Complex, NE Atlantic continental margin; executive summary. Mar. Pet. Geol. 2005, 22, 1-9.

38. Weibull, W.; Mienert, J.; Bünz, S.; Hustoft, S. Fluid migration directions inferred from gradient of time surfaces of the sub seabed. Mar. Pet. Geol. 2010, 27, 1898-1909. 
39. Bjørnseth, H.; Grant, S.; Hansen, E.; Hossack, J.; Roberts, D.; Thompson, M. Structural evolution of the Vøring Basin, Norway, during the Late Cretaceous and Palaeogene. J. Geol. Soc. 1997, $154,559-563$.

40. Brekke, H. The tectonic evolution of the Norwegian Sea Continental Margin with emphasis on the Vøring and Møre Basins. Geol. Soc., Lond., Special Publ. 2000, 167, 327-378.

41. Lundin, E.; Doré, A.G. Mid-Cenozoic post-breakup deformation in the "passive" margins bordering the Norwegian-Greenland Sea. Mar. Pet. Geol. 2002, 19, 79-93.

42. Rise, L.; Ottesen, D.; Berg, K.; Lundin, E. Large-scale development of the mid-Norwegian margin during the last 3 million years. Mar. Pet. Geol. 2005, 22, 33-44.

43. Berg, K.; Solheim, A.; Bryn, P. The Pleistocene to recent geological development of the Ormen Lange area. Mar. Pet. Geol. 2005, 22, 45-56.

44. Eldholm, O.; Thiede, J.; Taylor, E. Evolution of the Norwegian continental margin: Background and Objectives. In Proceedings of the Ocean Drilling Programme, College Station, TX, USA, 1987 ; p. 21.

45. Klitgaard-Kristensen, D.; Sejrup, H.P.; Haflidason, H. The last 18 kyr fluctuations in Norwegian Sea surface conditions and implications for the magnitude of climatic change: Evidence from the North Sea. Paleoceanography 2001, 16, 455-467.

46. ICES Oceanographic Database and Services, 2008. Available online: http://www.ices.dk/ocean/ (accessed on December 20, 2010).

47. Bugge, T.; Belderson, R.H.; Kenyon, N.H. The Storegga Slide. Philos. Trans. R. Soc. Lond., Ser. A 1988, 325, 357-388.

48. Bouriak, S.; Vanneste, M.; Saoutkine, A. Inferred gas hydrates and clay diapirs near the Storegga Slide on the southern edge of the Vøring Plateau, offshore Norway. Mar. Geol. 2000, 163, 125-148.

49. Mienert, J.; Bryn, P. Gas hydrate drilling conducted on the European margin. Eos, Trans. Am. Geophys. Union 1997, 78, 567.

50. Hovland, M.; Svensen, H.; Forsberg, C.F.; Johansen, H.; Fichler, C.; Fosså, J.H.; Jonsson, R.; Rueslåtten, H. Complex pockmarks with carbonate-ridges off mid-Norway: Products of sediment degassing. Mar. Geol. 2005, 218, 191-206.

51. Hovland, M.; Svensen, H. Submarine pingoes: Indicators of shallow gas hydrates in a pockmark at Nyegga, Norwegian Sea. Mar. Geol. 2006, 228, 15-23.

52. Ivanov, M.; Blinova, V.; Kozlova, E.; Westbrook, G.; Mazzini, A.; Minshull, T.; Nouzé, H. First Sampling of Gas Hydrate From the Vøring Plateau. Eos, Trans. Am. Geophys. Union 2007, 88.

53. Andreassen, K.; Mienert, J.; Bryn, P.; Singh, S. A Double Gas-Hydrate Related Bottom Simulating Reflector at the Norwegian Continental Margin. Ann. N. Y. Acad. Sci. 2000, 912, 126-135.

54. Berndt, C.; Büenz, S.; Mienert, J. Polygonal fault systems on the mid-Norwegian margin: A long-term source for fluid flow. In Subsurface Sediment Mobilization; van Rensbergen, P., Hills, R., Maltman, A., Morley, C., Eds.; Geological Society of London: London, UK, 2003; Volume 216, pp. 283-290.

55. Hustoft, S.; Mienert, J.; Bünz, S.; Nouzé, H. High-resolution 3D-seismic data indicate focussed fluid migration pathways above polygonal fault systems of the mid-Norwegian margin. Mar. Geol. 2007, 245, 89-106. 
56. Bünz, S.; Mienert, J.; Vanneste, M.; Andreassen, K. Gas hydrates at the Storegga Slide: Constraints from an analysis of multicomponent, wide-angle seismic data. Geophysics 2005, 70, B19-B34.

57. Bünz, S.; Mienert, J. Acoustic imaging of gas hydrate and free gas at the Storegga Slide. J. Geophys. Res. 2004, 109, 15.

58. Westbrook, G.; Chand, S.; Rossi, G.; Long, C.; Bünz, S.; Camerlenghi, A.; Carcione, J.; Dean, S.; Foucher, J.P.; Flueh, E.; Gei, D.; Haacke, R.; Madrussani, G.; Mienert, J.; Minshull, T.; Nouzé, H.; Peacock, S.; Reston, T.; Vanneste, M.; Zillmer, M. Estimation of gas hydrate concentration from multi-component seismic data at sites on the continental margins of NW Svalbard and the Storegga region of Norway. Mar. Pet. Geol. 2008, 25, 744-758.

59. Gorman, A.R.; Senger, K. Defining the updip extent of the gas hydrate stability zone on continental margins with low geothermal gradients. J. Geophys. Res. 2010, 115, B07105.

60. Weibull, W. Geological Fluid Flow Systems at Nyegga of the Mid-Norwegian Margin. Master Thesis, University of Troms $\emptyset$, Troms $\varnothing$, Norway, 2008; p. 145.

61. Paull, C.; Ussler, W.; Holbrook, W.; Hill, T.; Keaten, R.; Mienert, J.; Haflidason, H.; Johnson, J.; Winters, W.; Lorenson, T. Origin of pockmarks and chimney structures on the flanks of the Storegga Slide, offshore Norway. Geo-Mar. Lett. 2008, 28, 43-51.

62. Bünz, S.; Mienert, J.; Berndt, C. Geological controls on the Storegga gas-hydrate system of the mid-Norwegian continental margin. Earth Planet. Sci. Lett. 2003, 209, 291-307.

63. Faverola, A.P.; Bünz, S.; Mienert, J. Fluid distributions inferred from P-wave velocity and reflection seismic amplitude anomalies beneath the Nyegga pockmark field of the mid-Norwegian margin. Mar. Pet.Geol. 2010, 27, 46-60.

64. Norwegian Geotechnical Institute. Møre and Vøring Soil Investigation 1997 Part B-Geotechnical Data; Technical Report for Norwegian Geotechnical Institute, Oslo, Norway, 1997.

65. Statoil Ltd. Zero Offset VSP 6404/5 GB1. Final Report SP-22-RE-01R-00000-98; Technical Report for Read Well Services, for Statoil and the Seabed Project: Hvalstad, Norway, 1998.

66. Milkov, A.V.; Claypool, G.E.; Lee, Y.J.; Xu, W.; Dickens, G.R.; Borowski, W.S.; ODP Leg 204 Scientific Party. In situ methane concentrations at Hydrate Ridge, offshore Oregon: New constraints on the global gas hydrate inventory from an active margin. Geology 2003, 31, 833-836.

67. Stoian, I. Seismic studies of gas hydrate in the Ulleung Basin, East Sea, offshore Korea. Master Thesis, University of Victoria, British Columbia, Canada, 2008.

68. Claypool, G. Gulf of Mexico Gas Hydrate Joint Industry Project (GOMJIP), 2005. The cruise of the drilling vessel Uncle John, Mobile, Alabama to Galveston, Texas, Atwater Valley Blocks 13/14 and Keathley Canyon Block 151, 17 April to 22 May 2005; Technical Report for NETL: Morgantown, WV, USA, 2006.

69. Cook, A.E.; Goldberg, D.; Kleinberg, R.L. Fracture-controlled gas hydrate systems in the northern Gulf of Mexico. Mar. Pet. Geol. 2008, 25, 932-941.

70. Kastner, M.; Claypool, G.; Robertson, G. Geochemical constraints on the origin of the pore fluids and gas hydrate distribution at Atwater Valley and Keathley Canyon, northern Gulf of Mexico. Mar. Pet. Geol. 2008, 25, 860-872. 
71. Chen, Y.; Ussler, W.; Haflidason, H.; Lepland, A.; Rise, L.; Hovland, M.; Hjelstuen, B.O. Sources of methane inferred from pore-water [delta]13C of dissolved inorganic carbon in Pockmark G11, offshore Mid-Norway. Chem. Geol. 2010, 275, 127-138.

72. Hustoft, S.; Bünz, S.; Mienert, J. Three-dimensional seismic analysis of the morphology and spatial distribution of chimneys beneath the Nyegga pockmark field, offshore mid-Norway. Basin Res. 2010, 22, 465-480.

73. Hustoft, S.; Bünz, S.; Mienert, J.; Chand, S. Gas hydrate reservoir and active methane-venting province in sediments on 20Ma young oceanic crust in the Fram Strait, offshore NW-Svalbard. Earth Planet. Sci. Lett. 2009, 284, 12-24.

74. MacDonald, G. The future of methane as an energy resource. Annu. Rev. Energy 1990, 15, 53-83.

75. The Norwegian Petroleum Directorate. The petroleum resource account as of Dec. 31, 2009. Available online: http://www.npd.no/en/Topics/Resource-accounts-and-analysis/Temaartikler/ Resource-accounts/2009/ (accessed on December 20, 2010).

76. The Norwegian Petroleum Directorate. The NPD's Fact-pages. Available online: http://www.npd. no/engelsk/cwi/pbl/en/ (accessed on December 20, 2010).

77. Erichsen, L. The Peon Field, unlocking unconventional reserves in the North Sea. Presented at SPE Bergen "One Day Seminar", Bergen, Norway, 2009.

78. Milkov, A.; Sassen, R. Estimate of gas hydrate resource, northwestern Gulf of Mexico continental slope. Mar. Geol. 2001, 179, 71-83.

79. Pecher, I.; Henrys, S.; Gorman, A.; Fohrmann, M. Gas Hydrates on the Hikurangi and Fiordland Margins, New Zealand. In Proceedings of AAPG Hedberg Conference, Vancouver, Canada, 2004; p. 4.

80. Laberg, J.S.; Andreassen, K.; Knutsen, S.M. Inferred gas hydrate on the Barents Sea shelf-A model for its formation and a volume estimate. Geo-Mar. Lett. 1998, 18, 26-33.

81. Hovland, M.; Gallagher, J.W.; Clennell, M.B.; Lekvam, K. Gas hydrate and free gas volumes in marine sediments: Example from the Niger Delta front. Mar. Pet. Geol. 1997, 14, 245-255.

82. Milkov, A.V.; Sassen, R. Economic geology of offshore gas hydrate accumulations and provinces. Mar. Pet. Geol. 2002, 19, 1-11.

83. Lodolo, E.; Camerlenghi, A.; Madrussani, G.; Tinivella, U.; Rossi, G. Assessment of gas hydrate and free gas distribution on the South Shetland margin (Antarctica) based on multichannel seismic reflection data. Geophys. J. Int. 2002, 148, 103-119.

84. Fohrmann, M. The Occurrence and Distribution of Gas Hydrates on the Puysegur Continental Margin and Slope-Stability Aspects on Ritchie Banks, Hikurangi Margin, New Zealand. Ph.D. Thesis, University of Otago, Dunedin, New Zealand, 2009; p. 244.

85. Gorman, A. Seismic characterization of gas hydrates and associated fluid flow on passive and active continental margins: examples from New Zealand. Presented at CSEG Luncheon, Calgary, Canada, January 2008.

(C) 2010 by the authors; licensee MDPI, Basel, Switzerland. This article is an open access article distributed under the terms and conditions of the Creative Commons Attribution license (http://creativecommons.org/licenses/by/3.0/.) 